\title{
Ex Ante versus Ex Post Justifications for Intellectual Property1
}

\author{
Mark A. Lemley2
}

The traditional economic justification for intellectual property is well known. Ideas are public goods: they can be copied freely and used by anyone who is aware of them without depriving others of their use. ${ }^{3}$ But ideas also take time and money to create. Because ideas are so easy to spread and so hard to control, only with difficulty may creators recoup their investment in creating the idea. As a result, absent intellectual property protection, most would prefer to copy rather than create ideas, and inefficiently few new ideas would be created. The limitations of this classic theory are also well known. ${ }^{4}$ Nonetheless, it is the standard economic explanation for intellectual property in the United States. ${ }^{5}$ I refer to this standard explanation as an "ex ante" justification for intellectual property, since under this conception, the goal of intellectual property is to influence behavior that occurs before the right comes into being.

Of late, commentators and courts have invoked new justifications for intellectual property protection. These arguments focus not on the incentive to create new ideas, but on what happens to those ideas after they have been developed. One 
form of the new justifications argues that intellectual property protection is necessary to encourage the intellectual property owner to make some further investment in the improvement, maintenance, or commercialization of the product. Another strand argues that such protection is necessary to prevent a sort of "tragedy of the commons" in which the new idea will be overused. I refer to both these new arguments as "ex post" justifications for intellectual property, because they defend intellectual property rights not on the basis of the incentives they give to create new works but on the basis of the incentives the right gives its owner to manage works that have already been created. ${ }^{6}$

Distinguishing between ex ante and ex post justifications for intellectual property is more than just a philosophical exercise. ${ }^{7}$ The different explanations entail very different consequences for the scope, duration, and enforcement of intellectual property rights. Under the classical incentive story, intellectual property is a necessary evil. We grant creators exclusive rights in their works-permitting them to charge a supracompetitive price ${ }^{8}$-to encourage them to make such works in the first place. This supracompetitive price in turn artificially depresses the consumption of the newly created work: some people who would be willing to pay more than the marginal cost of a copy of the idea will not be able to have access to it. Further, the exclusive control intellectual property rights grant to pioneers may stifle the invention of improvers. As a result, the incentive theory of intellectual property dictates that 
intellectual property rights should be granted only where necessary

The new ex post justifications, by contrast, endorse a greater and perhaps unlimited duration and scope of intellectual property rights. If the reason for granting intellectual property rights is to ensure that an invention, a movie, or a personal name is managed efficiently, there seems little reason to terminate that right after a period of years. Similarly, if intellectual property rights are designed to prevent overuse of an information resource, permitting significant unauthorized "fair use" by third parties would seem to undermine that goal. The ex post justifications seem to provide economic support for the legions of new intellectual property owners who claim a moral entitlement to capture all possible value from "their" information-a view that scholars have derided as "if value, then right." 9 Because the optimal intellectual property regime may look very different under an ex post approach than an ex ante approach, we should 
critically evaluate the claimed ex post justifications for intellectual property.

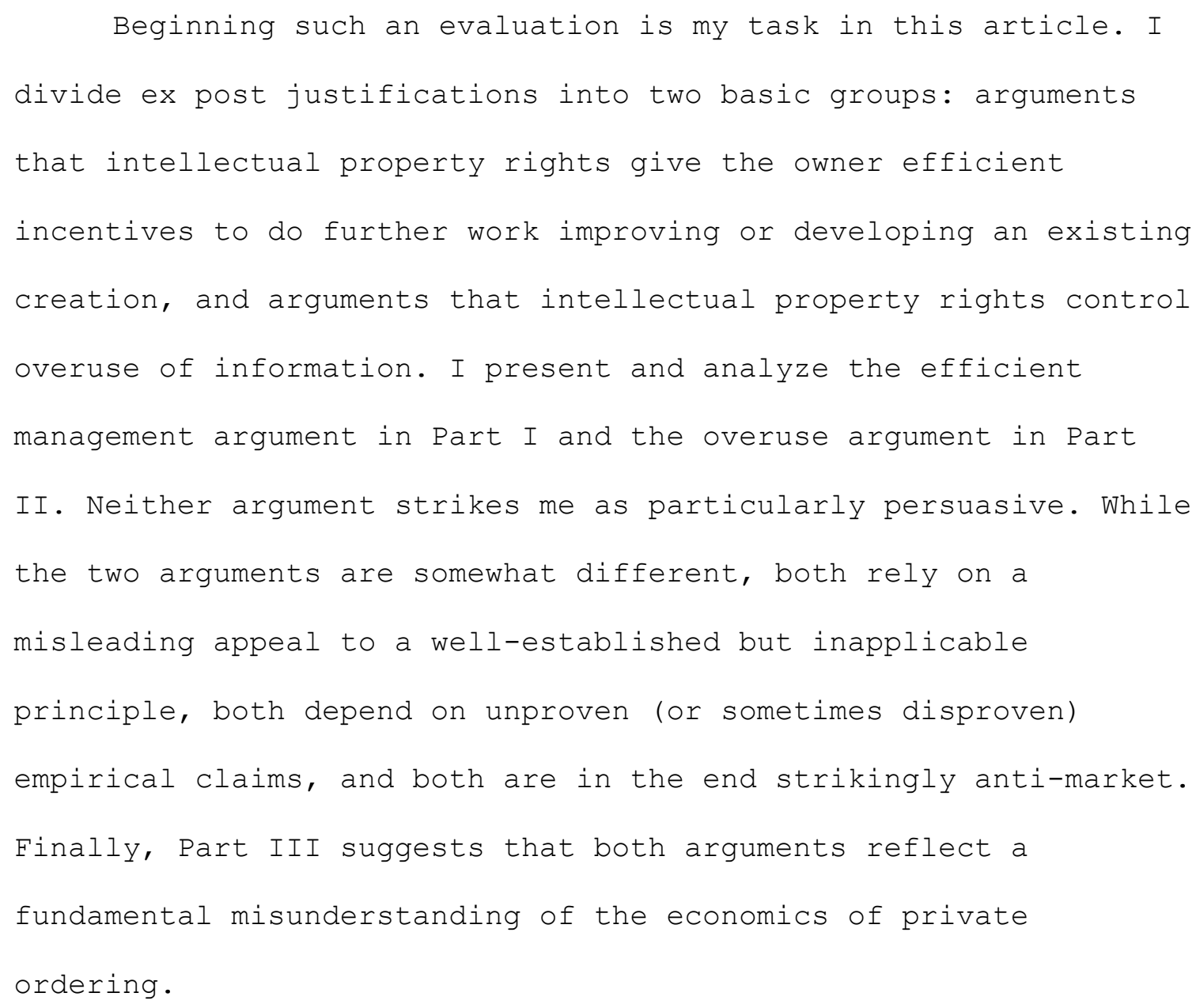


advance of an invention, making a patent a right to "prospect" a particular field for an invention. ${ }^{10}$ In Kitch's view, just as privatizing land will encourage the owner to make efficient use of it, the patent system will do the same for inventions. ${ }^{11}$ on this view, society as a whole should benefit from this equalization of private with social interests, as the patent owner will occupy the ideal position efficiently "to coordinate the search for technological and market enhancement of the patent's value. . . . ${ }^{12}$

Kitch's prospect theory follows from two premises. The first is that creators will not invest in putting their invention to efficient use unless they obtain exclusive rights to the invention, for "fear that the fruits of the investment will produce unpatentable information appropriable by competitors."13 Kitch's second premise-that the patent owner's monopoly right should result in efficient licensing to both end users and potential improvers-rests on the Coasian assumptions of perfect information, perfect rationality, and zero transaction costs. ${ }^{14}$ Beyond Kitch, others have argued that patents are valuable not just to create ex ante incentives to innovate but also because they create property rights that can in turn be the subject of bargaining $\cdot{ }^{15}$

The argument for intellectual property as a prospect right reappeared in dramatic form in the justifications offered for the Sonny Bono Copyright Term Extension Act, which added twenty more years to the already long copyright term. ${ }^{16}$ Congress obviously 
could not justify retroactive extension on the ground that it would encourage dead people to produce more works. ${ }^{17}$ Instead, Congress, the copyright industries, and even some prominent academics argued that extended intellectual property rights were necessary to give existing copyright owners incentive to preserve films they had already made and to distribute books they had already created. ${ }^{18}$ Once a work entered the public domain, they argued, it was an "orphan" and no one had any incentive to take care of it. ${ }^{19}$ The Register of Copyrights went further, testifying in hearings on the CTEA that "lack of copyright protection . . . restrains dissemination of the work, since publishers and other users cannot risk investing in the work unless assured of exclusive rights. . . [T] he copyright in the work represents a protection for the investment that is undertaken in the publication or production of the work." ${ }^{20}$ And the D.C. Circuit offered as one justification for upholding the CTEA the idea that more works would be available if copyright terms were extended than if the works entered the public domain. ${ }^{21}$ The argument here is that not just preservation but production and dissemination of copies require investment that will not occur absent exclusivity. ${ }^{22}$ The concern here mirrors Kitch's worry that patentees will not efficiently use their inventions if they cannot appropriate all the returns from those inventions. It hearkens back to the English Crown's grant of patents on existing products, a practice abolished by the statute of Monopolies in $1624 .{ }^{23}$ In both cases, the optimal right would appear to be 
perpetual: if only ownership gives efficient incentives to use, the right of stewardship of a film or an invention should never end.

B.Analysis of the Argument

The argument that a single company is better positioned than the market to make efficient use of an idea should strike us as jarringly counterintuitive in a market economy. Our normal supposition is that the invisible hand of the market will work by permitting different companies to compete with each other. It is competition, not the skill or incentives of any given firm, that drives the market to efficiency. Nothing about the fact that a work was once subject to copyright or patent protection should change our intuition here. It is hard to imagine senators, lobbyists, and scholars arguing with a straight face that the government should grant one company the perpetual right to control the sale of all paper clips in the country, on the theory that otherwise no one will have an incentive to make and distribute paper clips. ${ }^{24}$ We know from long experience that companies will make and distribute paper clips if they can sell them for more than it costs to supply them. The market for paper clips functions just fine without this type of government intervention. We can also predict with some confidence that if we did grant one company the exclusive right to make paper clips, the likely result would be an increase in the price and a decrease in the supply of paper clips. Yet supporters of the CTEA 
confidently predict exactly the opposite in the case of copyrighted works from the 1920s.

Are old books different than paper clips? Not because they are copyrighted, for paper clips were once patented, ${ }^{25}$ and the modern plastic variant was patented quite recently. ${ }^{26}$ Not because paper clips are an economic market and James Joyce's Ulysses is not. Indeed, both paper clips and Ulysses face competition in an economic market, but neither faces perfect competition. The owner of an exclusive right to either would have some power to raise the price above marginal cost-power that results from the fact that neither product has a perfect substitute-but that power would be significantly constrained by the existence of other works that could serve some of the same purposes. ${ }^{27}$ Is there some greater need to subsidize the making of more copies of Ulysses than the making of more paper clips? It is hard to see why; in both cases, once an intellectual property right expires, many companies can compete to make the good, and they will do so only so long as they can manufacture and distribute the work for less money than people will pay to buy it. This doubtless means that some inefficient manufacturers will stop selling Ulysses (or paper clips), but that shouldn't worry us. Indeed, if we believe in the market economy, it should delight us.

Empirical evidence strongly supports the intuition of the market, not the arguments of the lobbyists and ex post theorists. A comparison of copyrighted works from the 1920 s with public 
domain works from the $1910 \mathrm{~s}$ and $1920 \mathrm{~s}$ reveals that far more public domain works than copyrighted works are actually distributed to the public, and generally at a somewhat lower price. In percentage terms, twice as many books published in 1920 (and therefore in the public domain) are in print today than books published in $1930 .{ }^{28}$ Similarly, films already in the public domain are more likely to be preserved than films that are the subject of copyright. ${ }^{29}$ Not only is the argument that monopoly increases distribution counterintuitive, it is empirically incorrect. ${ }^{30}$

Further, even if we believed that books or paper clips needed a manager to be efficiently distributed, it does not follow that the creator is likely to be the most efficient manager. Creators are often terrible managers. They frequently misunderstand the significance of their own invention and the uses to which it can be put. ${ }^{31}$ And many patent owners are "paper patentees" who never even built their invention; giving them control over distribution hardly seems a recipe for success. The problem is even worse for copyright and the right of publicity because of the length of the term of protection. Even if we thought creators would be good managers, there is no reason to believe that the grandchildren of creators will be. If we are to grant perpetual rights to a curator of a work to get efficient management, and not because of any sense that we must further encourage creativity, it seems far more logical to give such control to a professional versed in such management. ${ }^{32}$ On this 
view, the argument for copyright term extension justifies not additional rights given to the great-grandchildren of creators, but transfer of those rights to archivists, film preservationists, and the like. At the very least, the right should be auctioned, rather than passed on as part of an estate. Yet it seems unlikely that Congress would do any such thing, no doubt because preserving films and books is not the real reason for the CTEA. ${ }^{33}$

Why then does the argument seem to have resonance? The answer lies in a sort of intellectual free-riding by supporters of the CTEA. They have taken the logic of intellectual property law as a solution to the public goods problem and applied it to circumstances in which there is no public goods problem. We need to give creators of patented and copyrighted works power over price because the act of creation imposes a cost that imitators do not share. There is no similar cost imbalance when it comes to the distribution of a work that has already been created. Some companies may be more efficient manufacturers and distributors than others, but we need not worry that no one will distribute a work without a monopoly incentive. If people are willing to pay enough to justify printing copies of Ulysses, copies of Ulysses will be printed. And if people are not willing to pay even the marginal cost of printing, granting exclusive rights over ulysses wouldn't solve the problem. Indeed, it will make it worse-people who aren't willing to pay marginal cost surely won't pay the supracompetitive price sole owners can command. 
Insofar as the new ex post incentive theory suggests that control by a single firm is necessary to induce efficient distribution, therefore, it is theoretically flawed and empirically unsound. Nonetheless, it is worth considering a variant of the argument that has a more direct connection to the public goods story: the claim that only with exclusive rights will a creator have adequate incentives to improve on an existing work. This argument is more in line with Kitch's theory of patent "prospects" as incentives to search efficiently for improvements, just as mining prospects give incentives to search efficiently for ore. Kitch's argument justifies giving broad property rights to pioneer inventors on the expectation that they will best know how to improve their own inventions. William Landes and Richard Posner argue, for example, that we may need to grant copyright in ancient works that require large intellectual investment to edit or clean up for publication. ${ }^{34}$

This argument too strikes me as a perversion of the public goods story, though a less dramatic one than the "efficient distribution" claim. Kitch is surely correct that there is a public goods problem with improvements, just as there is with initial inventions. We must give some sort of supracompetitive incentive to engage in improvements. But the need to encourage improvements does not tell us who should receive the appropriate incentive. ${ }^{35}$ The logical a priori answer must be that the creator of the improvement should receive an intellectual property right, just as the creator of the initial invention received such a 
right. After all, while we speak of pioneers and improvers as different categories of inventors, in fact very few inventions are truly original. They all improve on existing technology in different ways. ${ }^{36}$ Granting intellectual property rights to the actual inventors of the protected technology seems best consonant with encouraging those inventors. If we are to change the rules for improvement and to give an initial creator the right to control the search for subsequent inventions, it must be because we believe that the market will not efficiently conduct that search even with the incentives that patent law holds out to potential improvers. ${ }^{37}$ Thus, this claim too is fundamentally antimarket: it trusts the government's choice of whom to grant control over an area of research and development rather than trusting the market to pick the best researcher.

The claim that an initial inventor is better suited to control research than the market is fundamentally an empirical one. As an empirical claim, it has been tested and found wanting. ${ }^{38}$ As a theoretical claim it is no more promising. ${ }^{39}$ It depends on a belief that merely because a company made an initial invention, it would be better informed than the host of companies who might otherwise compete to improve the invention. It also depends on the strict assumption of rational and efficient behavior by the firm coordinating the search. ${ }^{40}$ A competitive market might be counted on to discipline irrational or inefficient actors, but if the government were to grant control to one company, that company would not face significant market 
discipline. ${ }^{41}$ This is not to say Kitch's theory is never valid; indeed, I have argued elsewhere that it may help to explain patent law in the pharmaceutical industry. ${ }^{42}$ But prospect theory is most useful when conceived as a part of rather than in opposition to the classic public goods story. Prospect theory is needed when control over subsequent development is a necessary part of the incentive to produce the pioneering invention in the first place, as is arguably true with pharmaceuticals. ${ }^{43}$ Prospect theory as a justification for displacing the market for invention, by contrast, is not a helpful justification for intellectual property. ${ }^{44}$

\section{II.Preventing "OVergrazing" of IdeAs}

A. Nature and Origin of the Argument

In 1968, Garrett Hardin wrote his famous article in which he described the "tragedy of the commons." ${ }^{45}$ Common property, he explained, is likely to be overused as a multitude of private parties make whatever use they like of the commons, without regard for the costs their use imposes on others. This overuse explains why common fishing stocks are depleted and why common pastures are overgrazed. Private property solves the tragedy of the commons, he argued, because it causes the owner of a parcel of land to internalize the costs as well as the benefits of use. Scholars have increasingly adopted the idea of a "tragedy of the commons" as a justification for intellectual property. Some argue that certain intellectual property rights efficiently 
discourage overuse of the information that is the subject of the right. Thus, Landes and Posner claim that most economists believe that "all valuable resources, including copyrightable works, should be owned, in order to create incentives for their efficient exploitation and to avoid overuse."46 Gerard Magliocca argues that trademark dilution law provides a right to prevent overexploitation of a famous mark in a way that whittles away the mark's value. ${ }^{47}$ And a number of scholars have justified the right of publicity as a means of preventing "overexposure" of celebrities by allowing them to control the circumstances of their own publicity. ${ }^{48}$ The Federal Circuit has endorsed the latter theory, reasoning that "[w] ithout the artificial scarcity created by the protection of one's likeness, that likeness would be exploited commercially until the marginal value of its use is zero. . . [I]t would be overused, as each user will not consider the externality effect his use will have on others." ${ }^{49}$ This "tragedy of the information commons" theory is not only distinct from, but indeed largely at odds with, the classic incentive story. On this explanation, intellectual property rights exist not to encourage the creation and dissemination of an idea, but to efficiently suppress the overuse of the idea. Like other ex post justifications, however, the tragedy of the information commons argues in favor of strong, perpetual exclusive rights. 


\section{B.Analysis of the Argument}

The idea that granting exclusive rights over information will reduce the use and distribution of that information compared with an open market makes perfect sense. ${ }^{50}$ It is consistent with everything we know about basic economics. ${ }^{51}$ The question here is whether we should want to reduce the use and distribution of information when there is no public goods problem for intellectual property to solve. ${ }^{52}$ Reducing the distribution of information is a good thing if, but only if, such information is in fact overproduced or overdistributed. In other words, this justification for intellectual property depends on proof that there is in fact a tragedy of the commons in information.

The idea of a tragedy of the information commons, however, is fundamentally flawed because it misunderstands the nature of information. A tragedy of the commons occurs when a finite natural resource is depleted by overuse. Information cannot be depleted, however; in economic terms, its consumption is nonrivalrous. ${ }^{53}$ It simply cannot be "used up." ${ }^{54}$ Indeed, copying information actually multiplies the available resources, not only by making a new physical copy but by spreading the idea and therefore permitting others to use and enjoy it. ${ }^{55}$ The result is that rather than a tragedy, an information commons is a "comedy" in which everyone benefits. ${ }^{56}$ The notion that information will be depleted by overuse simply ignores basic economics.

Courts and scholars who have applied the tragedy of the commons to the right of publicity have made a slightly different 
argument: not that the resource itself will be depleted by "overuse," but that the value of the resource to its owner will decline with overuse. Indeed, they warn that if we do not grant to a single owner the right to control and limit uses, different people will use an idea until the marginal value of an additional use declines to zero. ${ }^{57}$ This is true enough. The real puzzle is why anyone would think it was bad for society. Economists have a term for markets in which different providers keep selling goods with less and less value until the point is reached where it would cost more to produce a good than the public is willing to pay for it. We call such a market "perfectly competitive," and we have thought for at least three centuries (since Adam Smith) that it is a good thing. It is true that if we gave only one person control over a particular type of information, that person would restrict the flow of information, raise its price, and make more money then providers do in a competitive market. But society as a whole would be worse off, since buyers who could afford to pay more than what it costs to provide the information still wouldn't receive it. We might have to accept such a market distortion if we thought that the control we granted over price would encourage new creation, but there is no such justification for the right of publicity

Like the argument discussed in Part I that we should grant control over distribution to encourage more distribution, the argument that we need to grant control over distribution to encourage less distribution is at base anti-market. We would 
never say that we will get an efficient amount of information about Iraq only by granting to one company plenary power over information about Iraq. Nor would we think that granting one company control over the distribution of information about Enron would lead to efficient reporting of information about Enron-and that goes double if the company that got that control was Enron itself. Instead, we let the market decide how much information people want or need about any given subject. Logically this should be just as true when the subject is a person rather than a company. ${ }^{58}$ Individual customers in information markets may get fed up with hearing about Monica Lewinsky or Lorena Bobbitt, but when they do they have a choice: stop paying attention.

But won't this market-based use of an idea or topic diminish its value to producers? It is true that permitting competition in the use of a piece of information will reduce its price relative to market exclusivity, and that if we gave an exclusive right to control that piece of information the controller would make more money than he would in a competitive market. But that supracompetitive return is not found money; it comes directly out of consumer surplus. And basic economics teaches us that what the owner gains from exclusive control is less than what consumers lose. ${ }^{59}$ We may be willing to give such control to an intellectual property owner if we think we will get something-the creation of a new idea-in return. But without such an incentive justification, there is no economic reason to grant such exclusive control. ${ }^{60}$ 
Landes and Posner make a more sophisticated argument-that consumers desire uniformity in their cultural icons, and that permitting a work to enter the public domain will allow its reuse in many different contexts, thus perhaps reducing the value consumers get from the work. ${ }^{61}$ The argument is that if we permit portrayals of Mickey Mouse as a drug dealer, or Barbie as a porn star, or Scarlett O'Hara abusing her slaves, these countercultural works will somehow infect the wholesome nature of the icon, ruining it for everyone else. In economic terms, Landes and Posner argue that the creation of unauthorized derivative works may have a demand-reducing effect on all works based on the original, overwhelming what they acknowledge is a positive economic effect from reducing price and expanding the potential market.

The demand-reducing effects argument may be true, though I am skeptical that it is a widespread enough phenomenon to serve as a justification for copyright or the right of publicity. First, it would seem to apply only to the subset of works that are so extremely well known that they have become cultural icons around which public expectations have crystallized. Thus, it is better as a justification for the right of publicity than for copyright, where Landes and Posner locate it. Second, there is substantial social value to allowing people to criticize and subvert cultural icons. ${ }^{62}$ At a minimum, that social value needs to be weighed against any demand-reducing effect. Third, the problem seems self-limiting. If customers want the original Gone with the 
Wind $^{63}$, not the rather more sordid story of The Wind Done Gone, ${ }^{64}$ there would not be a large market for the latter, and we shouldn't expect such works to proliferate sufficiently to drive out demand for the former. If they do proliferate, however, presumably we should question our intuition that customers want the real thing and not the retelling. ${ }^{65} \mathrm{~A}$ reduction in the value customers place on the original Gone with the Wind will likely occur only where there is a substantial increase in social value because a large group of people demand the retelling from the slave's perspective. Fourth, the prospect of competition to produce sequels may actually spur creators to write their own sequels more quickly and make them better. ${ }^{66}$ Finally, even at its strongest, Landes and Posner's argument justifies controls only on unauthorized derivative works, not controls on reproduction of copyrighted works that have entered the public domain. It therefore cannot justify indefinite copyright terms. ${ }^{67}$

The idea that an individual should get a right to control the dissemination of information about herself is even more troubling because it is likely not only to restrain the total amount of information but to affect the type and quality of the information we receive. Individuals have an obvious incentive to encourage flattering portrayals and discourage unflattering ones. Giving them a right to preclude parodies of themselves, to prevent photographers from recording events, and to stop artists from depicting them or cartoonists from lampooning them, as recent cases have sometimes done and as ex post theory would seem to 
endorse, 68 leads not to "efficient" management of information but to censorship. ${ }^{69}$ As with the "efficient stewardship" argument, even if we believed that granting exclusive rights would yield efficient distribution of information, there is no reason to believe that the subject of the information is best positioned to manage that distribution. Indeed, there are good reasons to believe otherwise. ${ }^{70}$

None of this is to say that there is no legitimate role for trademark law, trademark dilution, or the right of publicity, any more than rejecting the efficient stewardship argument meant there was no need for copyright or patent law. The right of publicity has traditionally been justified in one of two ways: as a way of preventing false or misleading uses of an individual's name or likeness, ${ }^{71}$ and as a way of preserving individual privacy. ${ }^{72}$ Both are valid justifications for a right of publicity, though these traditional explanations justify a right substantially less sweeping than the right courts have currently constructed. ${ }^{73}$ Similarly, trademark law has traditionally been justified as a means of preventing consumer confusion, and many of the recent expansions of that law can also be justified on that basis. ${ }^{74}$ There is no sound theoretical basis, however, for preventing competition in the creation and distribution of information about a person or company simply to give that person or company control over the market. 


\section{III.MISUNDERSTANDINGS ABOUT PRIVATE ORDERING}

In one sense, the two theories I discuss in this paper have little in common. One argues that exclusive control will increase the incentive to distribute information, while the other argues that exclusive control will have precisely the opposite effect. The theories are united, however, in their underlying assumption that central control, not market choice, will produce the most efficient outcome.

This assumption in turn seems to be driven by a peculiar sort of myopia about private ordering that is unfortunately very much in vogue. On the one hand, supporters of ex post justifications for intellectual property are very quick to conclude that the market will not produce efficient outcomes. They embrace the public goods or tragedy of the commons theories of market failure without detailed inquiry into whether or not such market failures actually exist. In point of fact, there is no evidence the market cannot function effectively in either case. On the other hand, advocates of these ex post justifications have an abiding faith in the knowledge, rationality, and good faith of the individual companies in whom they would vest control over the distribution of information, and appear completely unconcerned that transaction costs might prevent them from making efficient use of the power we have vested in them. ${ }^{75}$ Indeed, they seem to take it for granted that private companies wouldn't produce goods optimally unless they capture the full social value of those goods-that is, unless they can prevent free riding. ${ }^{76}$ The ex post 
justifications, in other words, seem to depend on private ordering without relying on market ordering.

This approach seems to me exactly backwards. Those who think that proper incentives require the elimination of free riding fundamentally misunderstand the lessons of economics. ${ }^{77}$ The genius of the competitive market is precisely that while no individual producer has the incentive to fill market demand perfectly, collectively producers will meet that demand. This is not because they capture the full social surplus from their behavior, which by definition is never true in a competitive market. It is because they have enough incentive to produce what consumers demand.

Individual companies are neither omniscient, pure-hearted, nor necessarily rational. Indeed, at best they are out to line their pockets with as much money as they can find. No less a capitalist than Adam Smith warned us not to expect individual private companies to behave in the public interest. ${ }^{78}$ The reason we can generally rely on private ordering to produce desirable outcomes is not because property has some inherently moral virtue that leads to efficient conduct, ${ }^{79}$ nor because individual companies can eliminate free riding, but because individual companies are constrained by the discipline of a competitive market. If they are irrational, or poorly informed, or too greedy, other companies will outperform them and take their place. But if we remove these constraints-if we rely on the decisionmaking of one company rather than the aggregate decisions of the market as a 


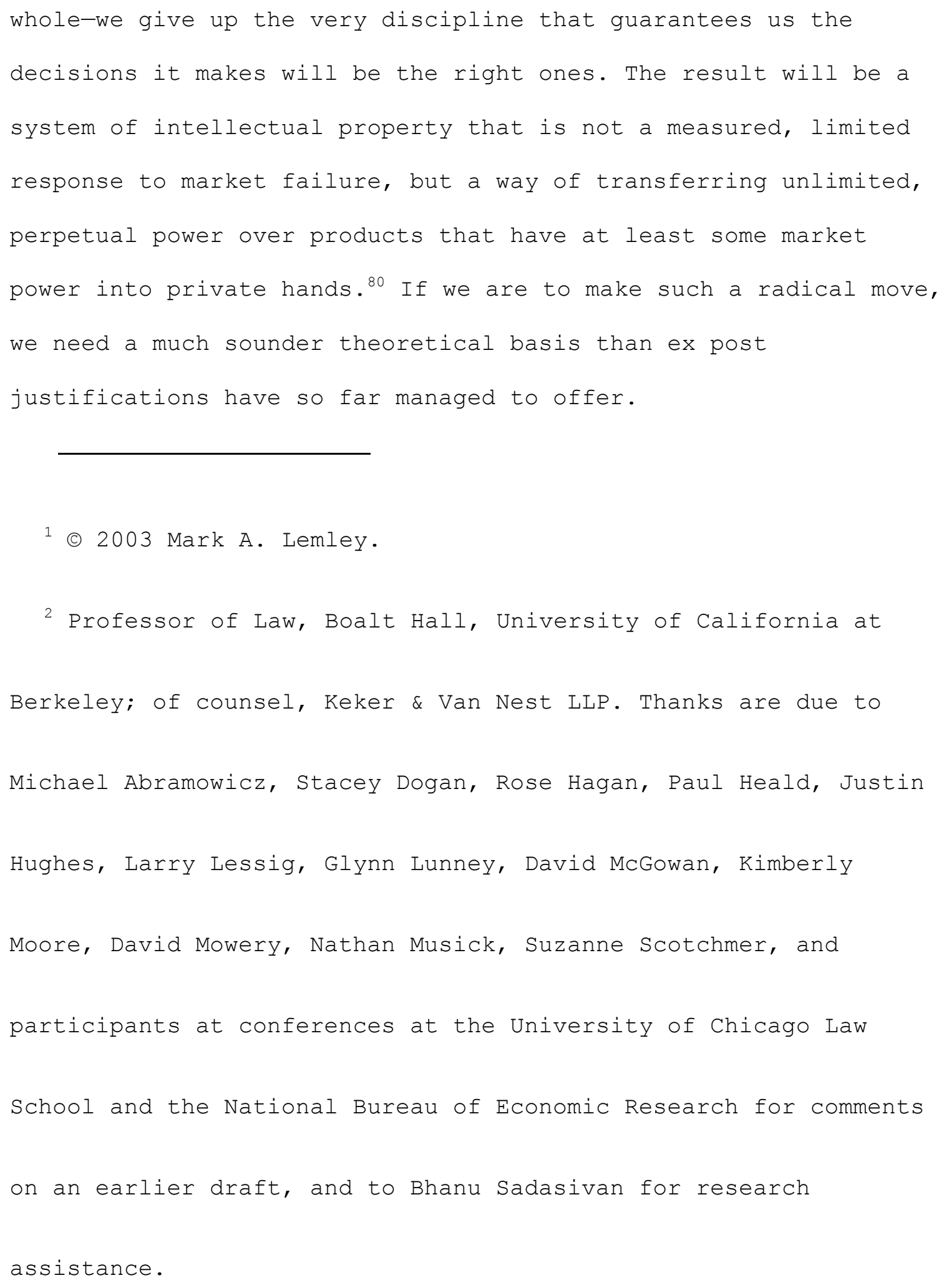


3 For a general discussion of the public goods characteristics of intellectual property, see Robert P. Merges, Peter S. Menell, and Mark A. Lemley, Intellectual Property in the New Technological Age 10-18 (Aspen 3d ed 2003).

${ }^{4}$ The incentive theory of intellectual property has two basic limits. First, innovation will not end absent intellectual property protection, and not just because of subsidies and noneconomic motives to create. See, for example, Michael Abramowicz, Perfecting Patent Prizes, 56 Vand L Rev 115 (2003) (analyzing reward system as substitute for intellectual property system); Yochai Benkler, Coase's Penguin, or, Linux and The Nature of the Firm, 112 Yale L J 369 (2002) (discussing the open-source software movement); Steven Shavell and Tanguy van Ypersele, Rewards Versus Intellectual Property Rights, $44 \mathrm{~J}$ L \& Econ 525, 537-40 (2001) (same). Second, intellectual property rights can 


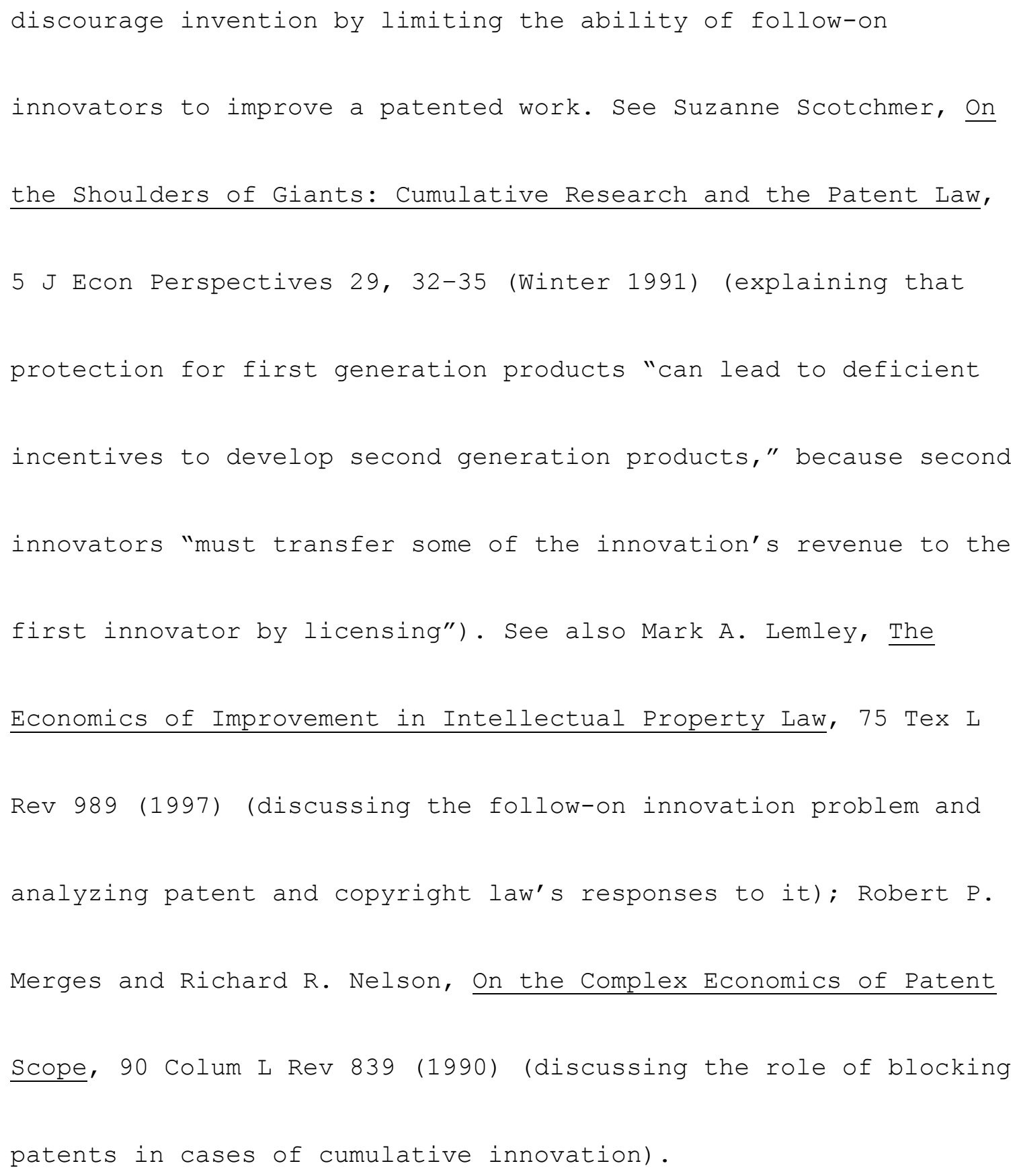


5 For a representative judicial expression, see Mazer v Stein, 347 US 201, 219 (1954) ("The economic philosophy behind the clause empowering Congress to grant patents and copyrights is the conviction that encouragement of individual effort by personal gain is the best way to advance public welfare. . ."). 6 Justin Hughes has argued to me that this distinction is exaggerated, since one substantial "ex ante" justification for intellectual property is to encourage distribution rather than mere creation. This is a fair point. I consider ex ante justifications to be those that go to the decision to invest initially in a work, even if that investment is made by an intermediary such as a publisher rather than by the author herself. By contrast, the ex post justifications I discuss here focus on management of the work after it has been created. 
${ }^{7}$ Consider Stephen L. Carter, Does It Matter Whether

Intellectual Property is Property?, 68 Chi-Kent L Rev 715 (1993).

8 On the relationship between intellectual property and

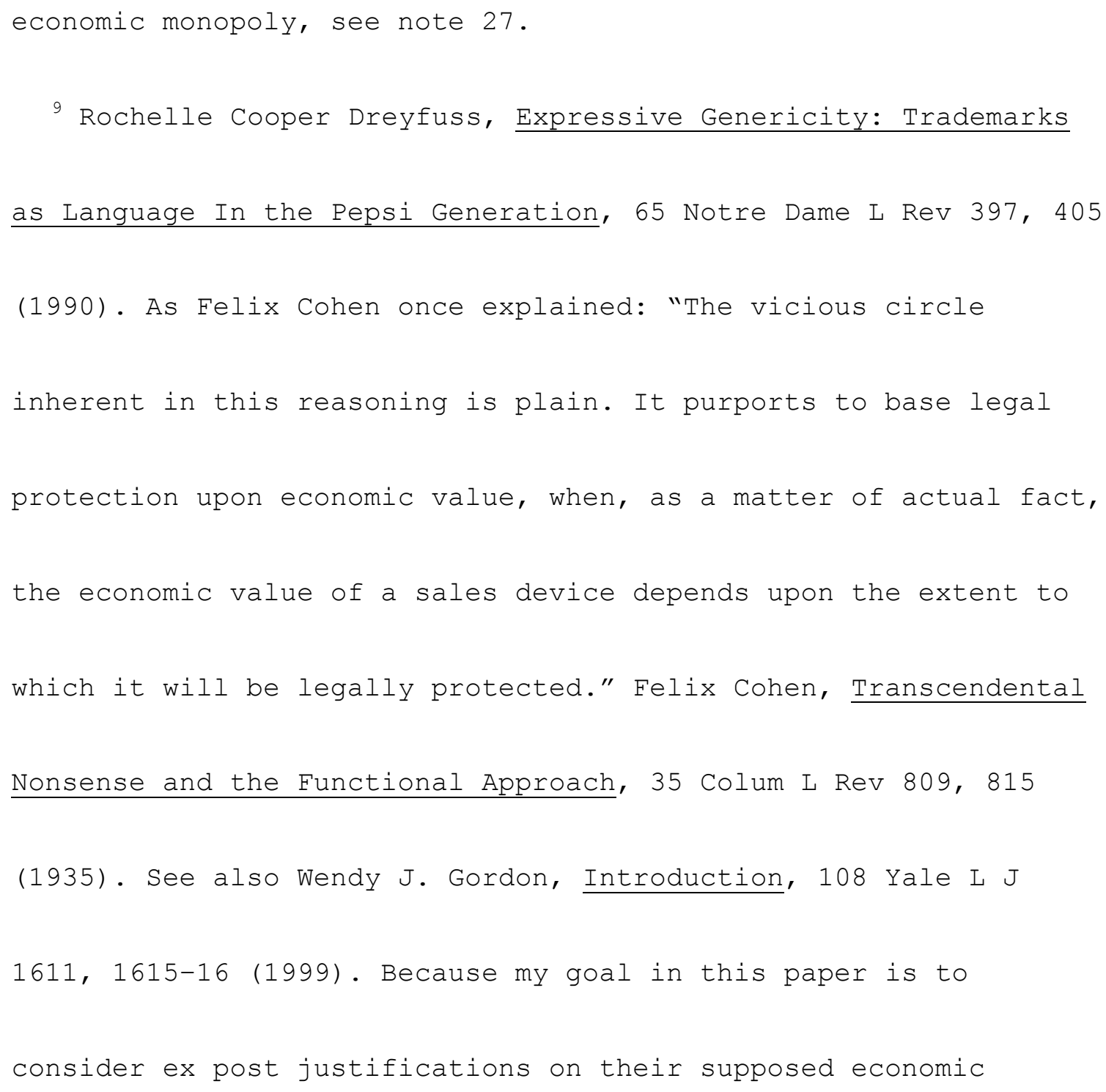




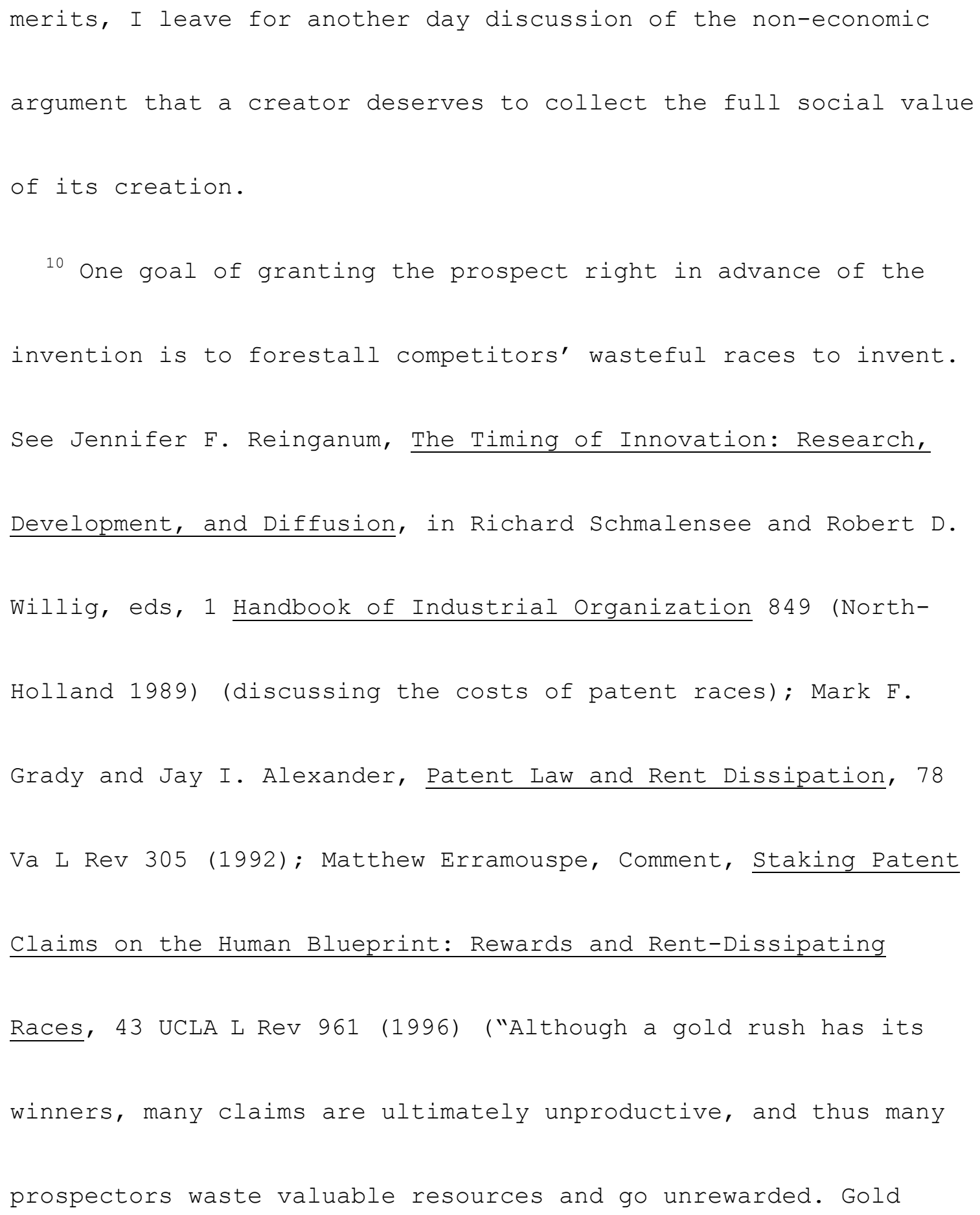




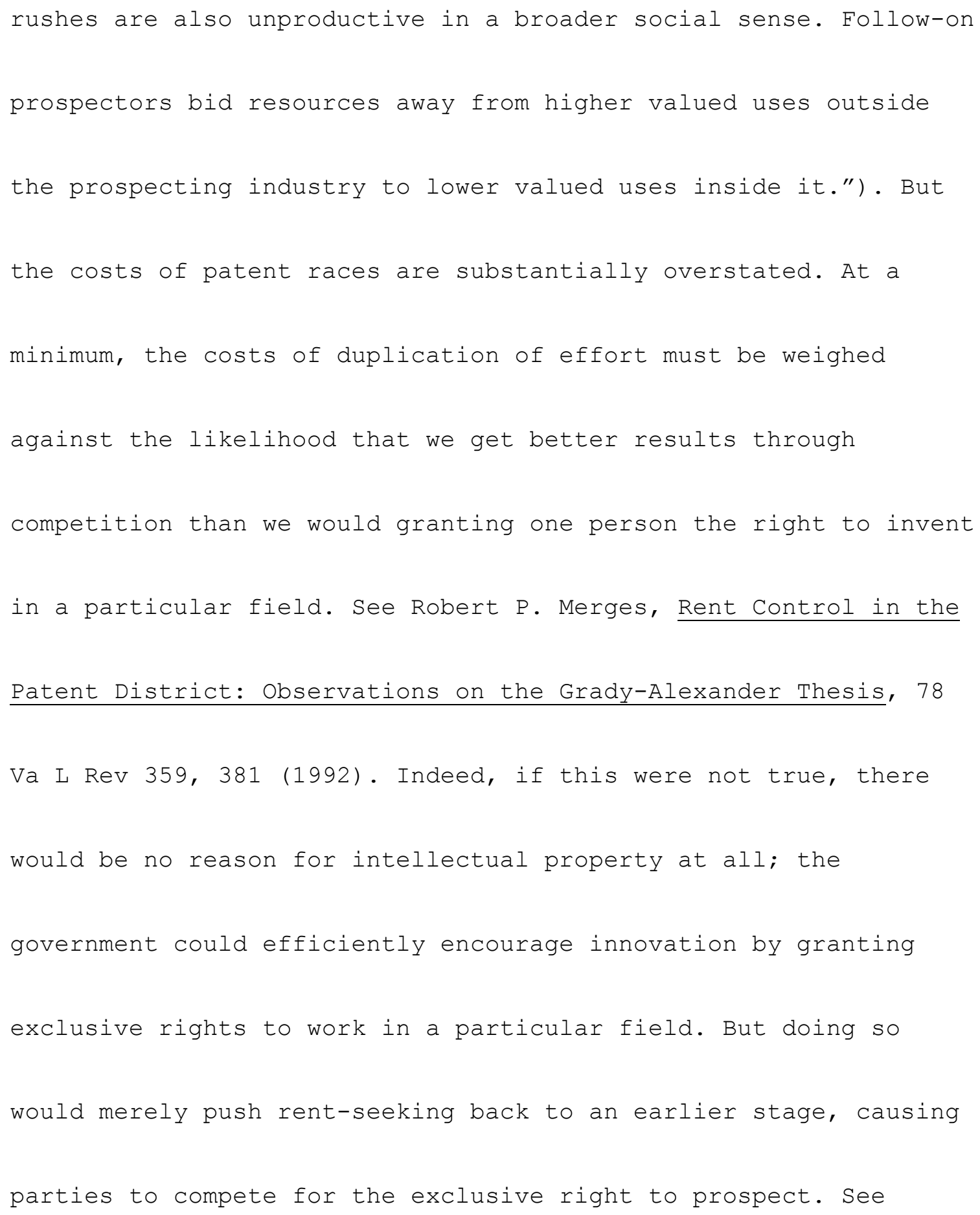




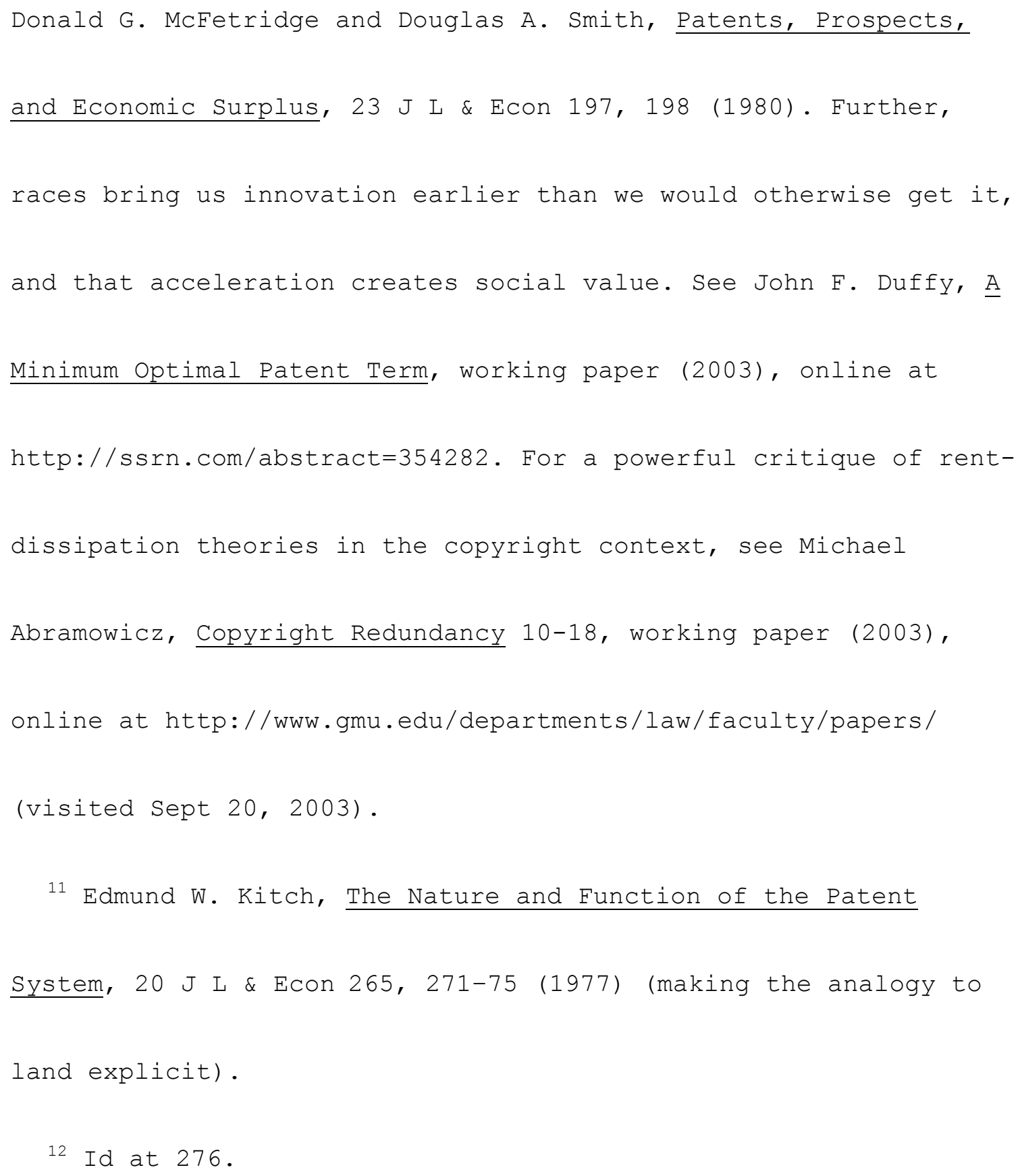


13 Id. Polk Wagner similarly argues that ex post control over ideas will give the owner more flexibility in building business models to make revenue from those ideas. R. Polk Wagner, Information Wants to be Free: Intellectual Property and the Mythologies of Control, 103 Colum L Rev 995 (2003). While he spends some time lauding the virtues of centralized control over market allocation, Wagner's argument ultimately falls back on ex ante incentive theory. He claims that because control can never be perfect, strengthening intellectual property protection would encourage more new invention that would in turn create positive spillovers to the public domain, outweighing the costs of enhanced protection. Wagner offers no empirical support for this supposition, and it seems likely we are far past the point where further strengthening of copyright protection produces more costs 


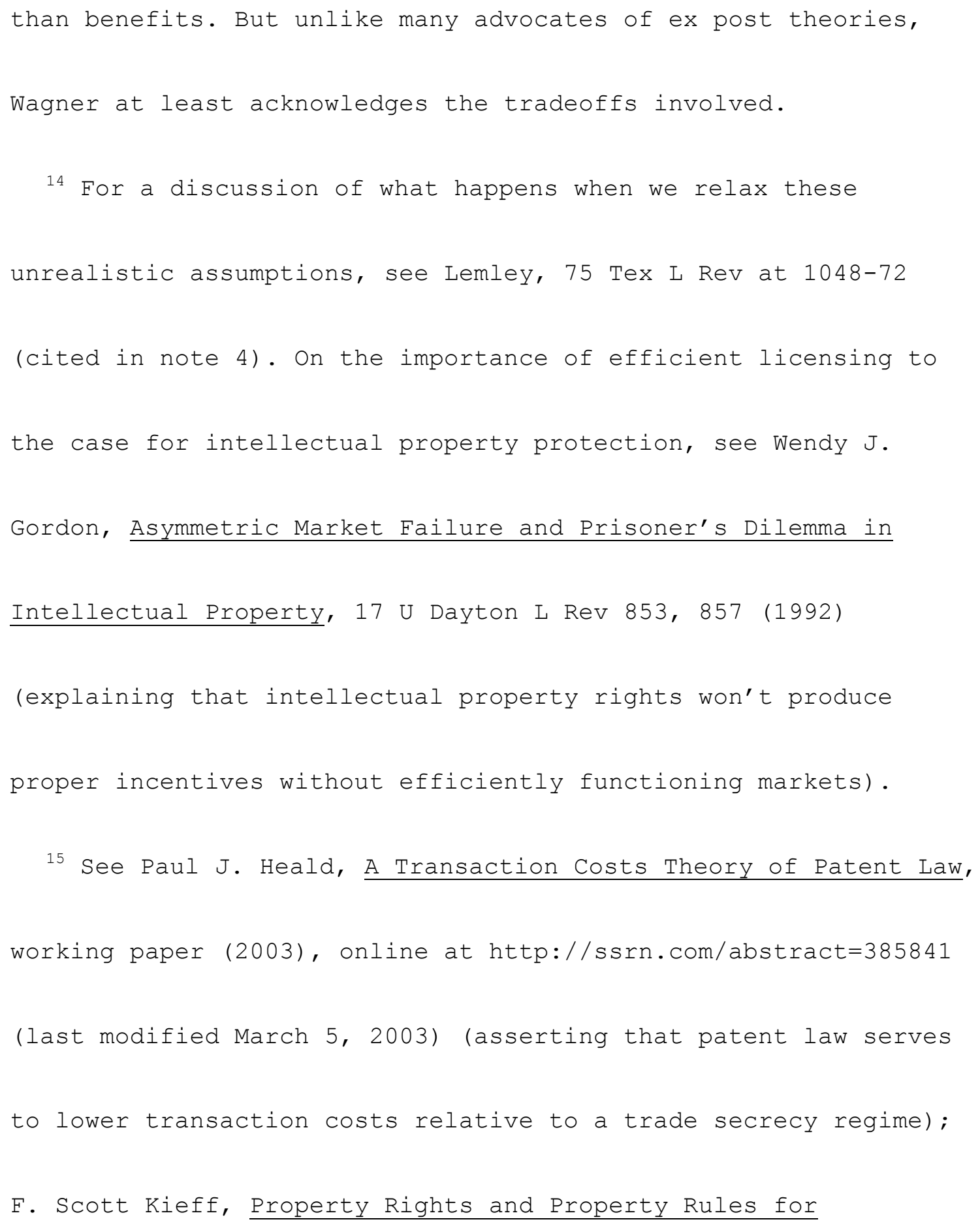




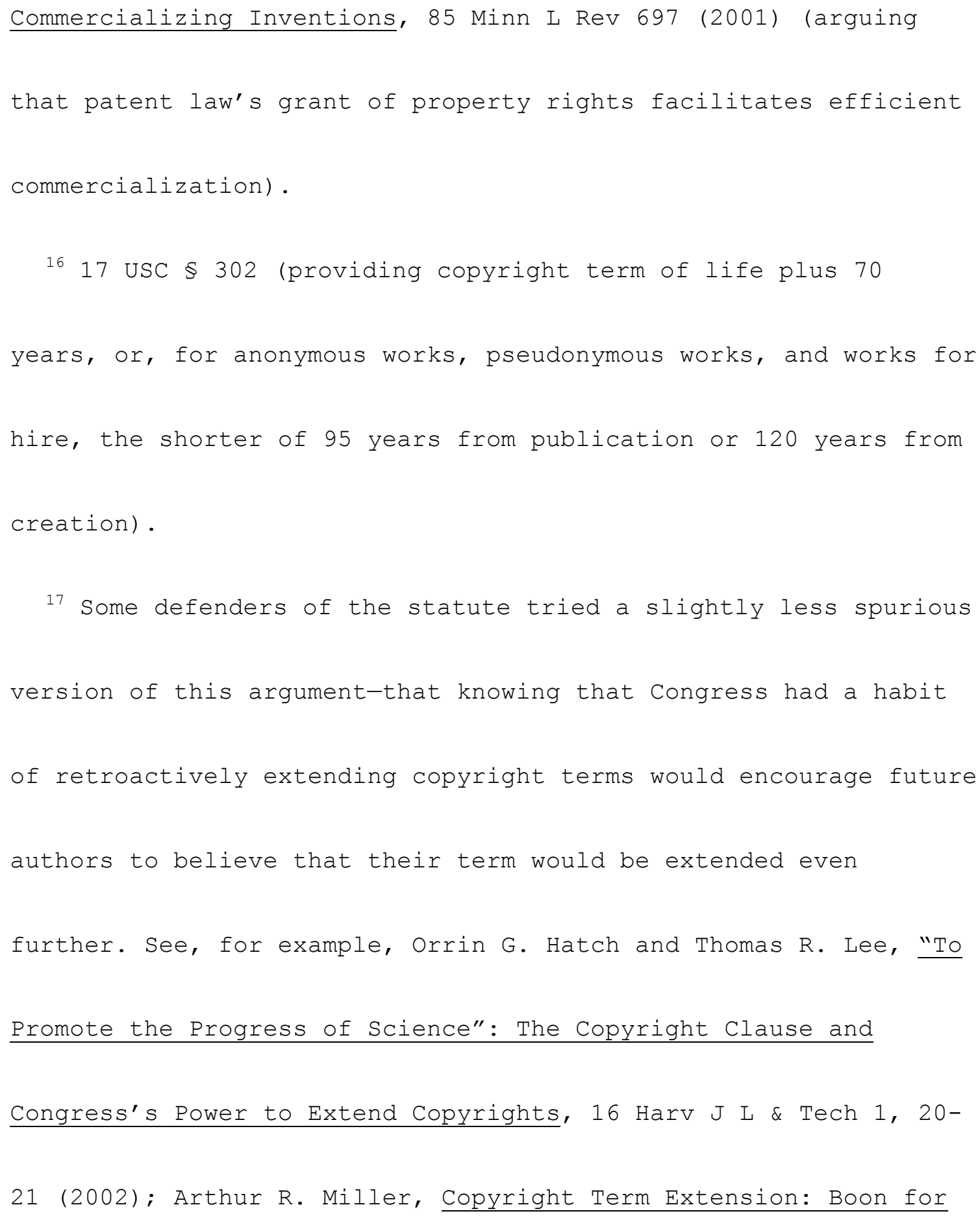




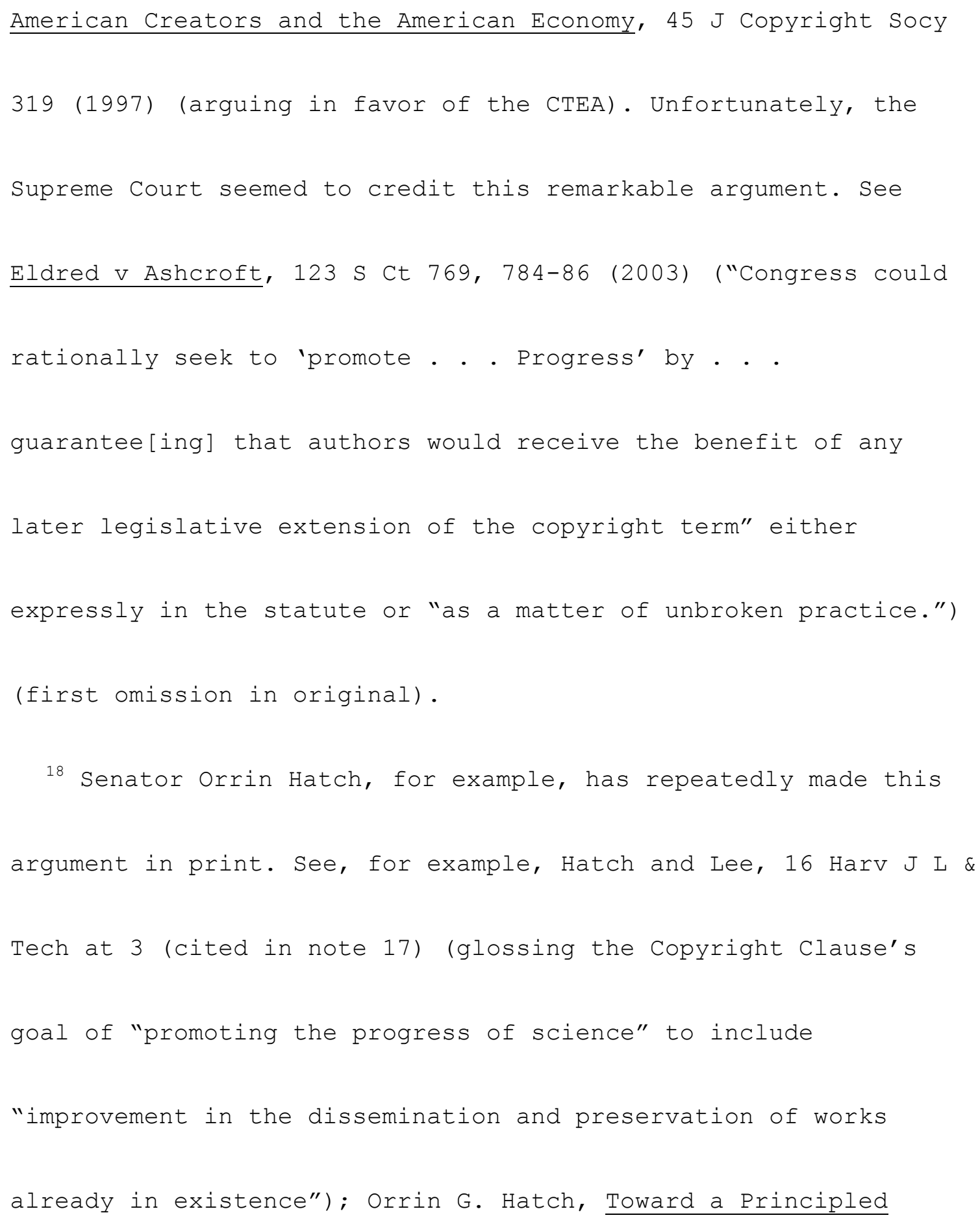


Approach to Copyright Legislation at the Turn of the Millennium, 59 U Pitt L Rev 719, 736-37 (1998) ("[T]he 20-year extension of copyright protection provides the important collateral benefit of creating incentives to preserve existing works."). Copyright industry groups made this argument to the supreme court in defense of the CTEA. See Brief of Amicus Curiae American Intellectual Property Law Association in Support of Respondent, Eldred V Ashcroft, No 01-618, *16-17 (Sup Ct filed Aug 5, 2002) available on Westlaw at 2002 WL 1822117; Brief of Amicus Curiae of the Nashville Songwriters Association International (NSAI) in Support of Respondent, Eldred V Ashcroft, No 01-618, *14 (Sup Ct filed Aug 2, 2002), available on Westlaw at 2002 WL 1808587

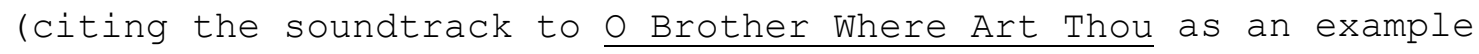
of copyright protection providing incentives to promote and develop older works). For an articulation in the academic 


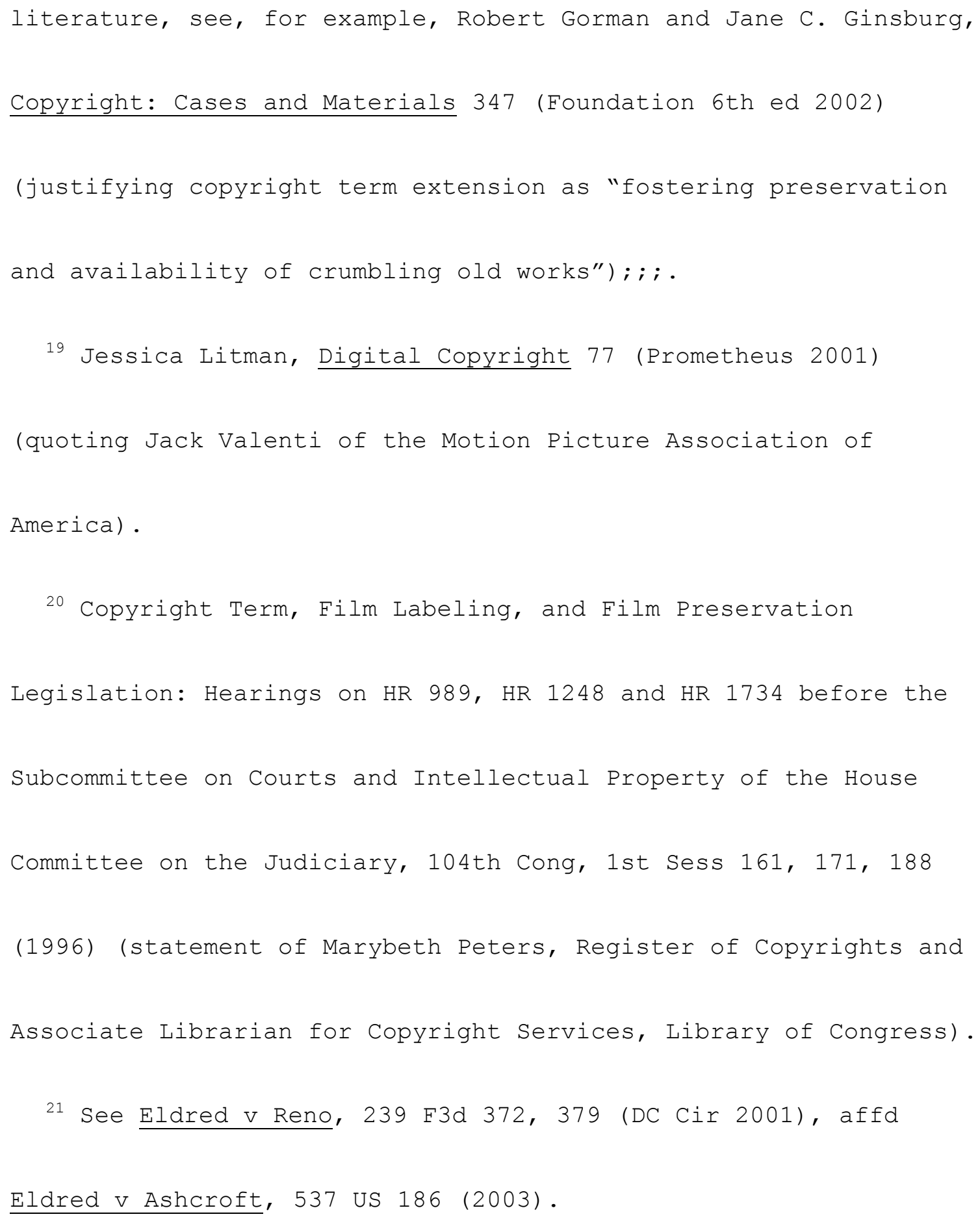


22 See Hatch and Lee 16 Harv $J$ L \& Tech at 16-17 (cited in note 17). Landes and Posner make a similar argument, speculating that the reason so few classical composers are recorded notwithstanding the existence of copyright protection for the new recordings is not because there is insufficient demand, but because copyright is insufficiently broad to capture the spillover effects that a successful recording of a musical composition by an undiscovered artist would have on the value of other works by that artist. William M. Landes and Richard A. Posner, Indefinitely Renewable Copyright, 70 U Chi L Rev 471, 492-93 (2003). They then reason that those who "rediscover" a public domain work should be able to reinvest it with intellectual property protection. Id at 493-94. The logical conclusion of their argument (though they do not draw it) is that copyrights should not only extend perpetually, but should be 


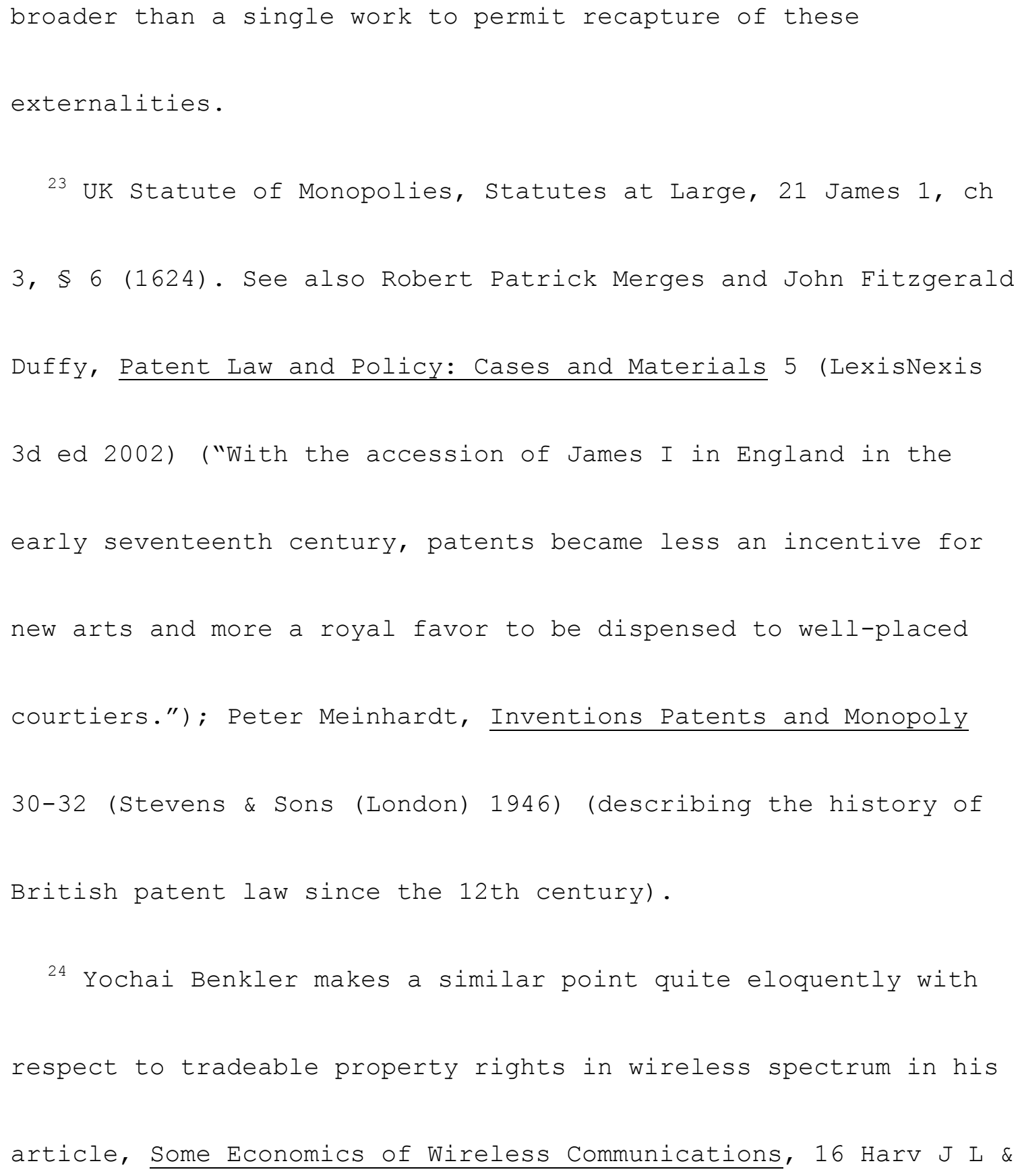




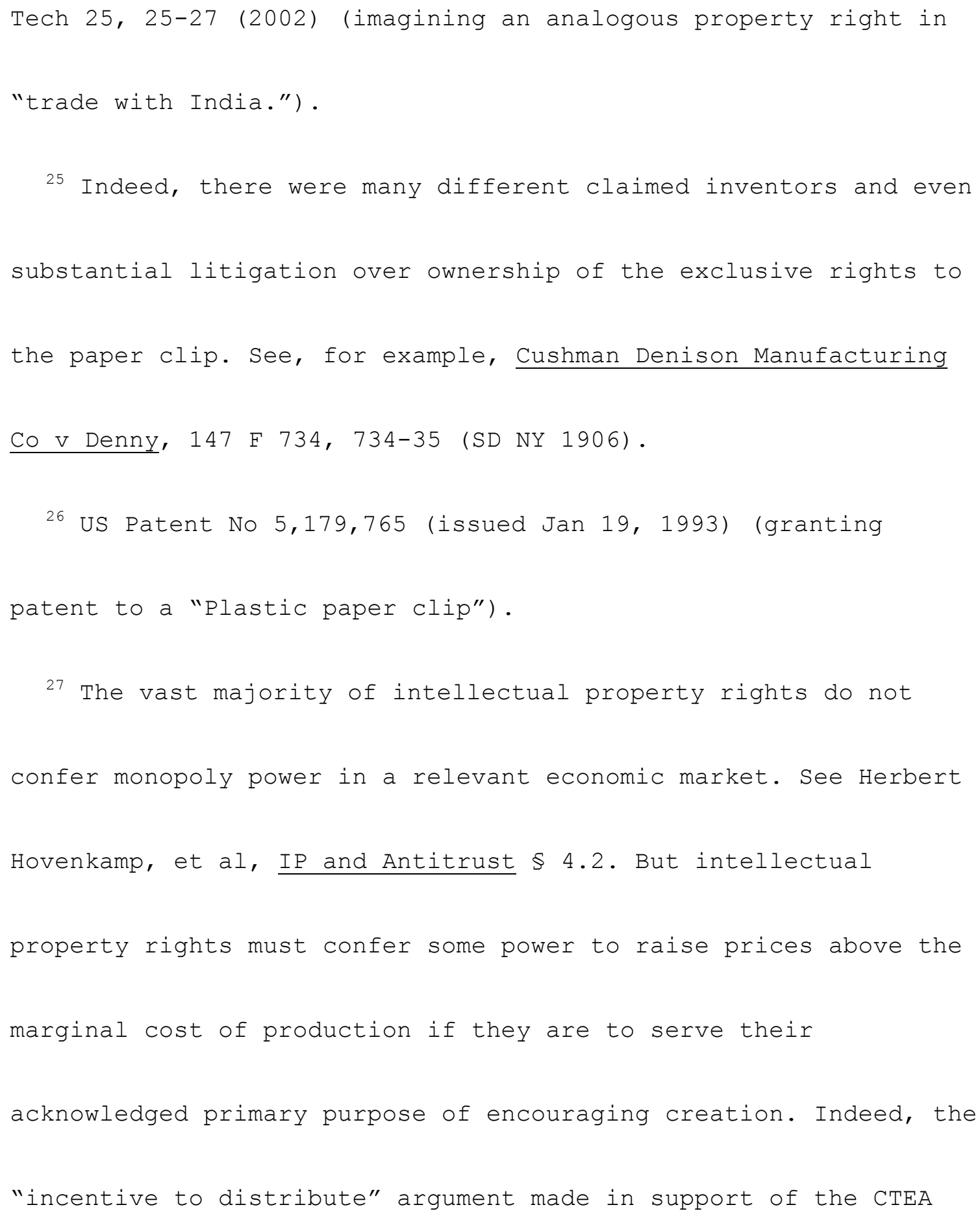




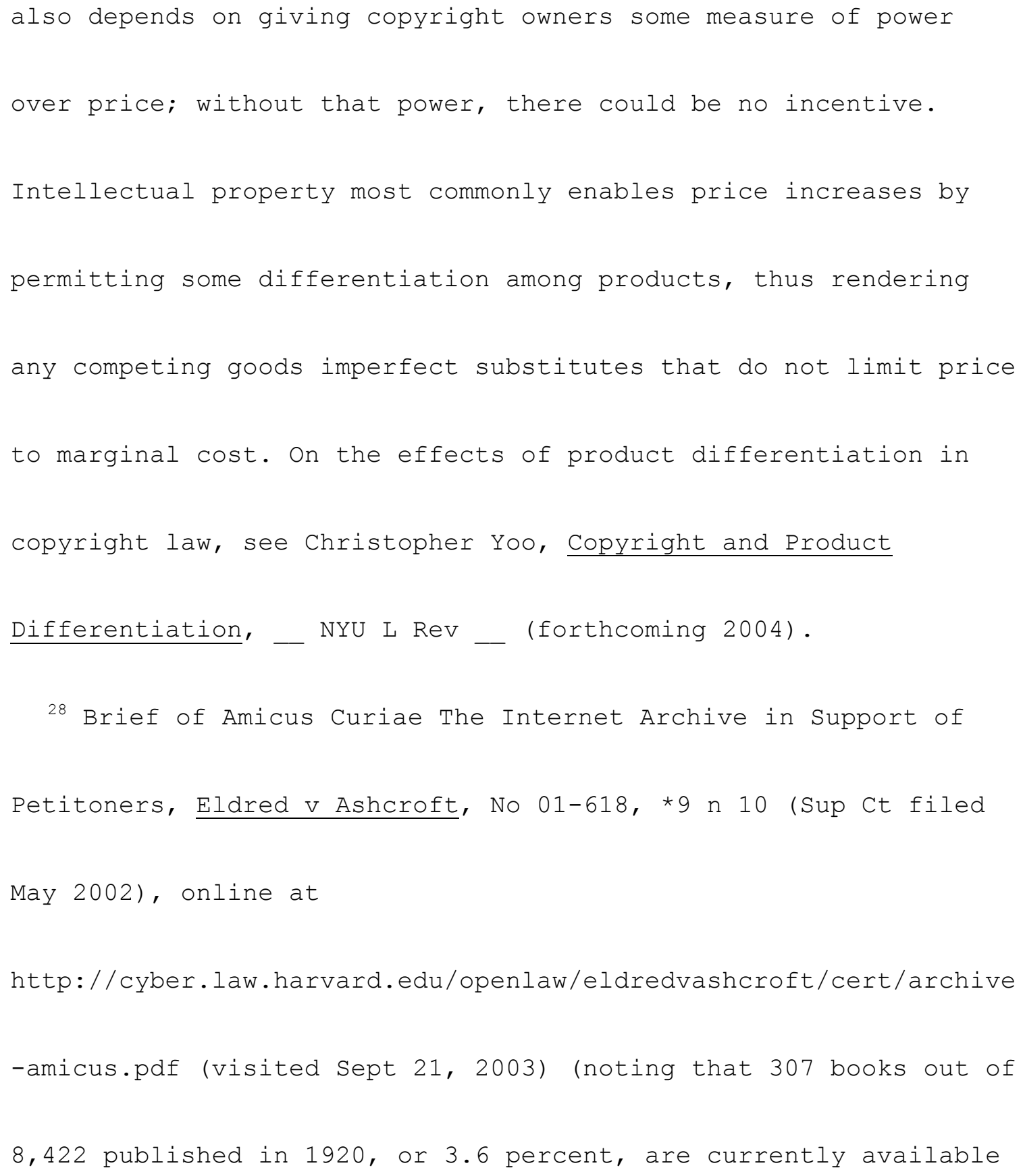




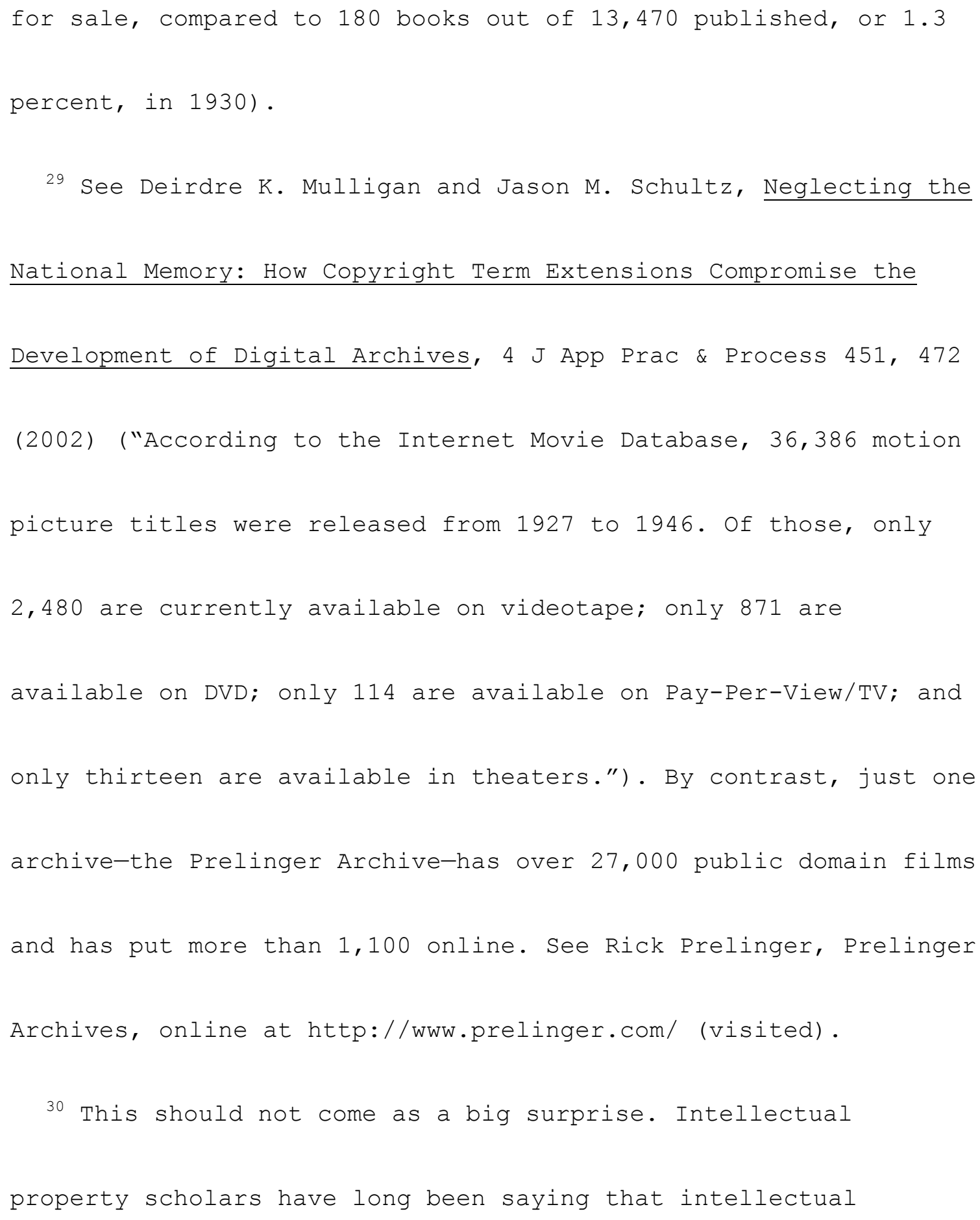




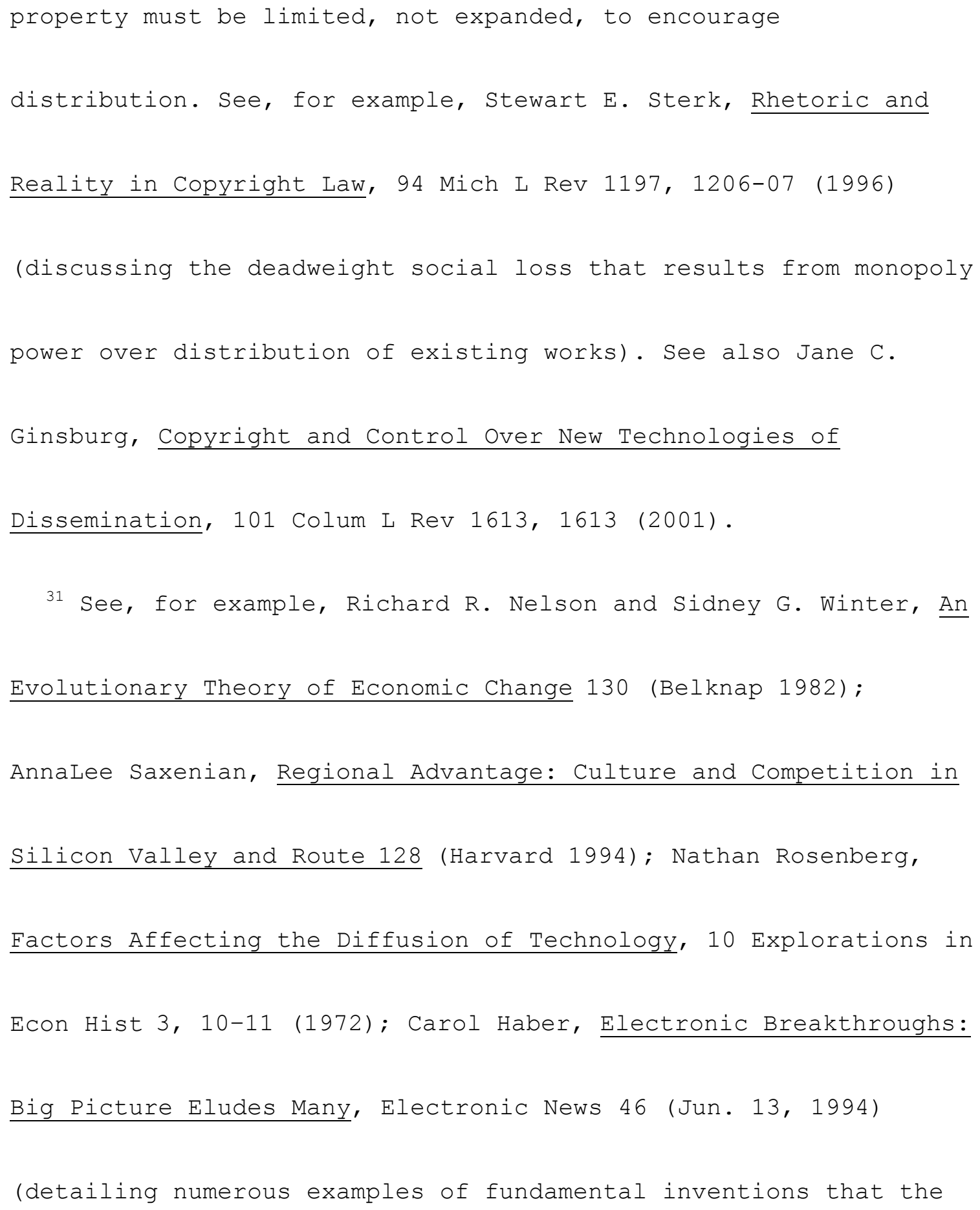




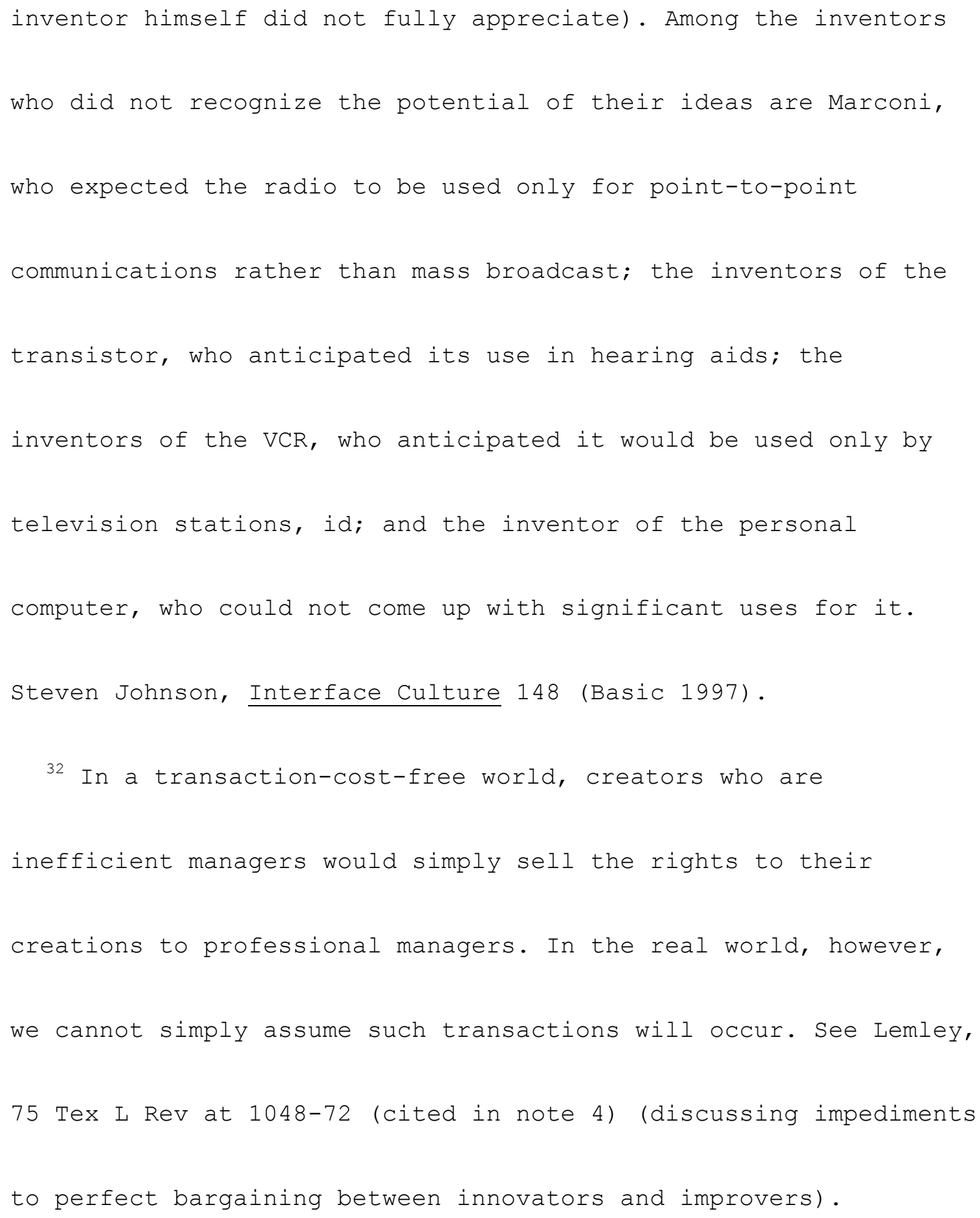


33 See Dennis S. Karjala, Judicial Review of Copyright Term

Extension Legislation, 36 Loyola LA L Rev 199, 234-35 (2002)

(referring to the film preservation argument as a "smokescreen,"

and noting that Congress rejected proposals that might actually

enhance film preservation). It is also worth noting that

professional curators were leading the fight against term

extension, which would seem odd if term extension would indeed

result in better stewardship.

34 Landes and Posner, $70 \mathrm{U}$ Chi L Rev at 491 (cited in note 22).

The fate of the Dead Sea Scrolls shows some of the dangers of

exclusive rights in restoration; the single group given exclusive

control over the Dead Sea Scrolls has spent decades working

without releasing much information to the public. See generally

David Nimmer, Copyright in the Dead Sea Scrolls: Authorship and 


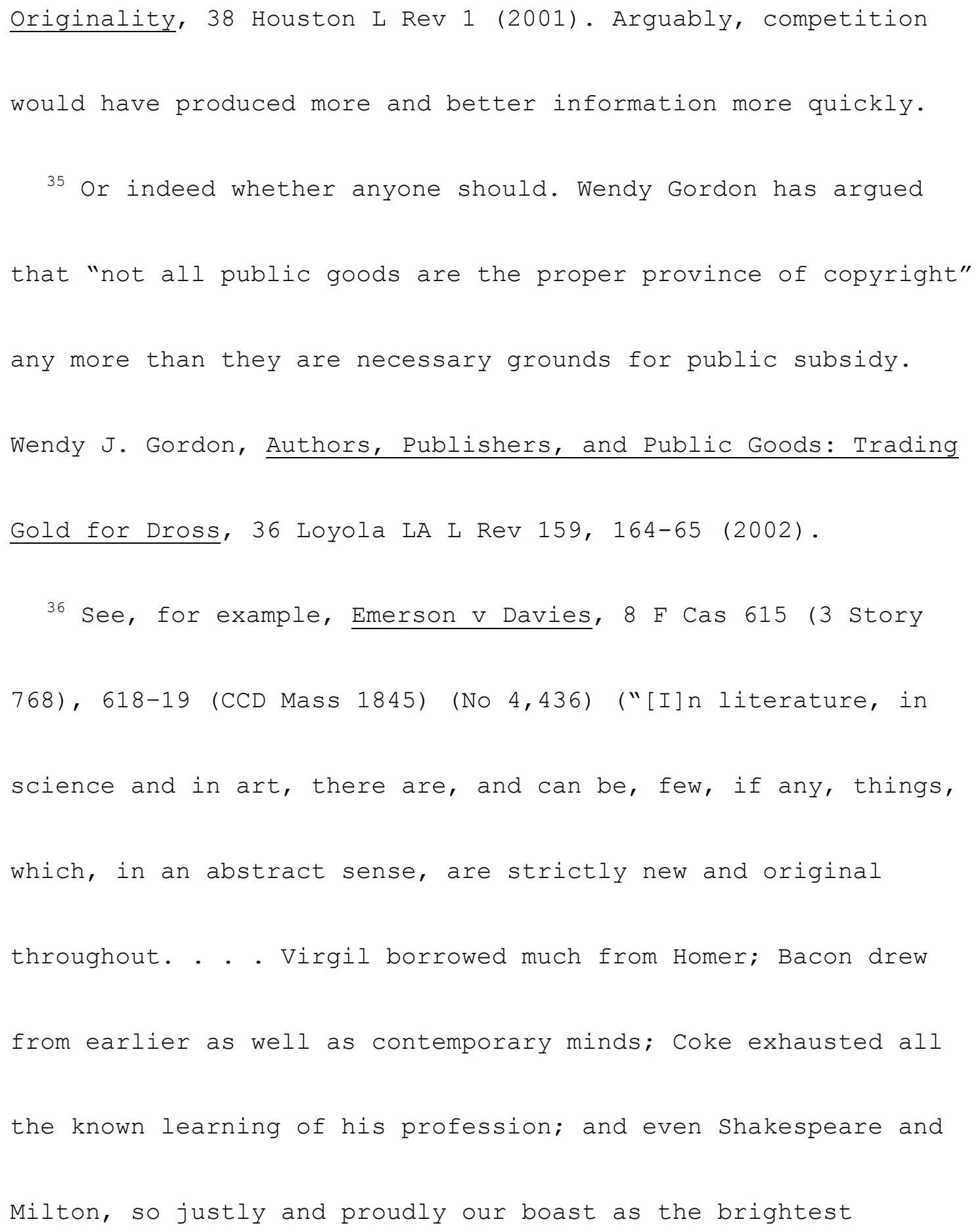


originals would be found to have gathered much from the abundant stories of current knowledge and classical studies in their days. . . . $"$ )

37 The classic argument cited in favor of monopolists

coordinating innovation is Joseph A. Schumpeter, Capitalism, Socialism, and Democracy 100-02 (Harper 2d ed 1947). For an application to patent law, see Kieff, 85 Minn L Rev 697 (2001); Kitch, $20 \mathrm{~J}$ L \& Econ 265 (1977) (cited in note 11) (arguing that the monopoly features of the patent system encourage efficient allocation of rights after an invention); Suzanne scotchmer, Protecting early innovators: should second-generation products be patentable?, 27 RAND J Econ 322 (1996) (proposing to weight incentives towards pioneers at the expense of improvers). The theory is that monopolists will have the resources to devote to research and development, and the fact that they can control all 


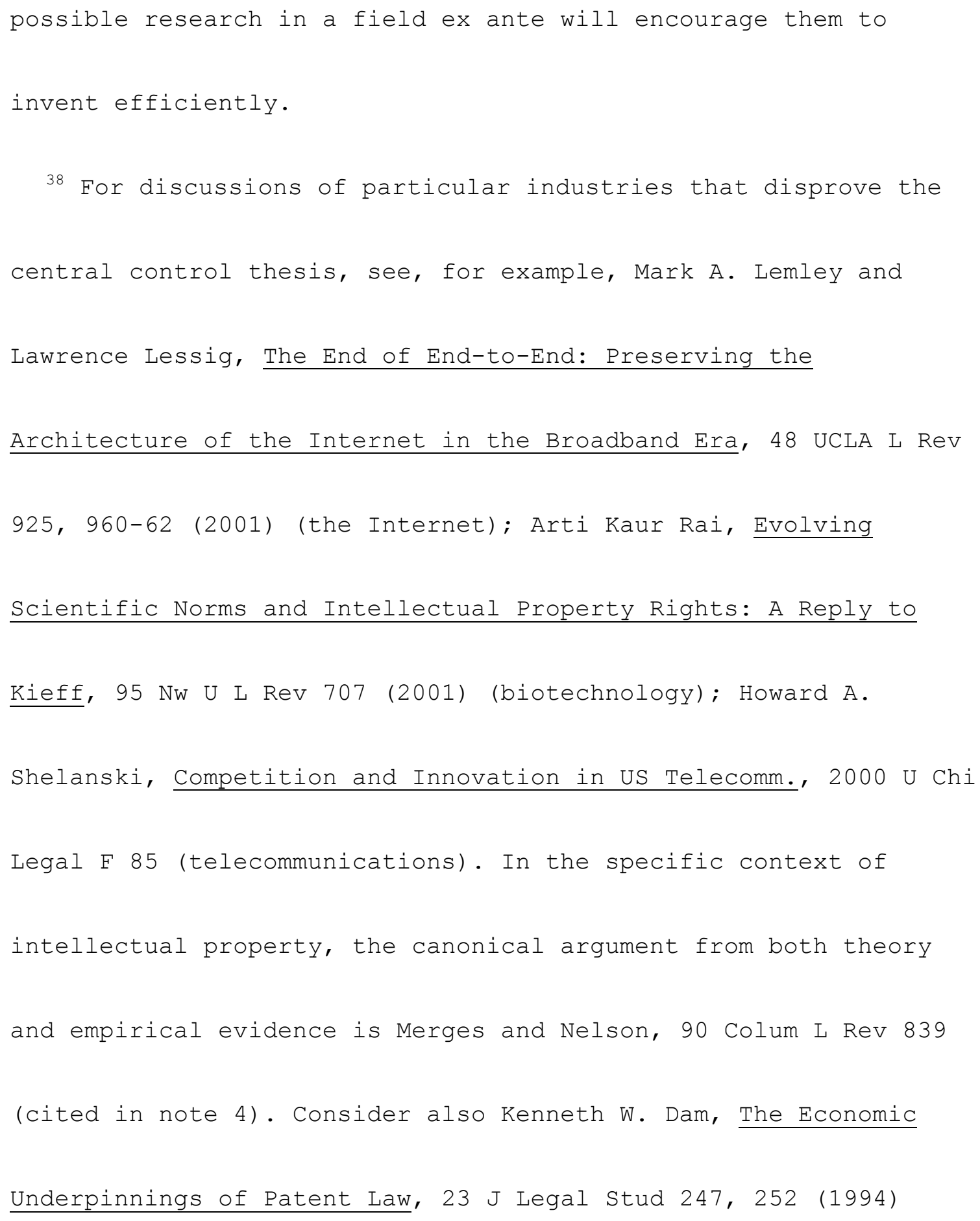


(noting that in the computer industry, for example, companies coordinate improvements by broad cross-licensing because of "the pace of research and development and the market interdependencies between inventions") .

39 See Kenneth J. Arrow, Economic Welfare and the Allocation of Resources for Invention, in National Bureau of Economic Research, The Rate and Direction of Inventive Activity: Economic and Social Factors 609, 620 (Princeton 1962) (concluding that "preinvention monopoly power acts as a strong disincentive to further innovation"). See also Morton I. Kamien and Nancy L. Schwartz, Market Structure and Innovation (Cambridge 1982) (discussing various theories of the effects of economic structures on the rate and form of innovation); F.M. Scherer and David Ross, Industrial Market Structure and Economic Performance 660 (Houghton Mifflin 3d ed 1990) (criticizing Schumpeter's "less 


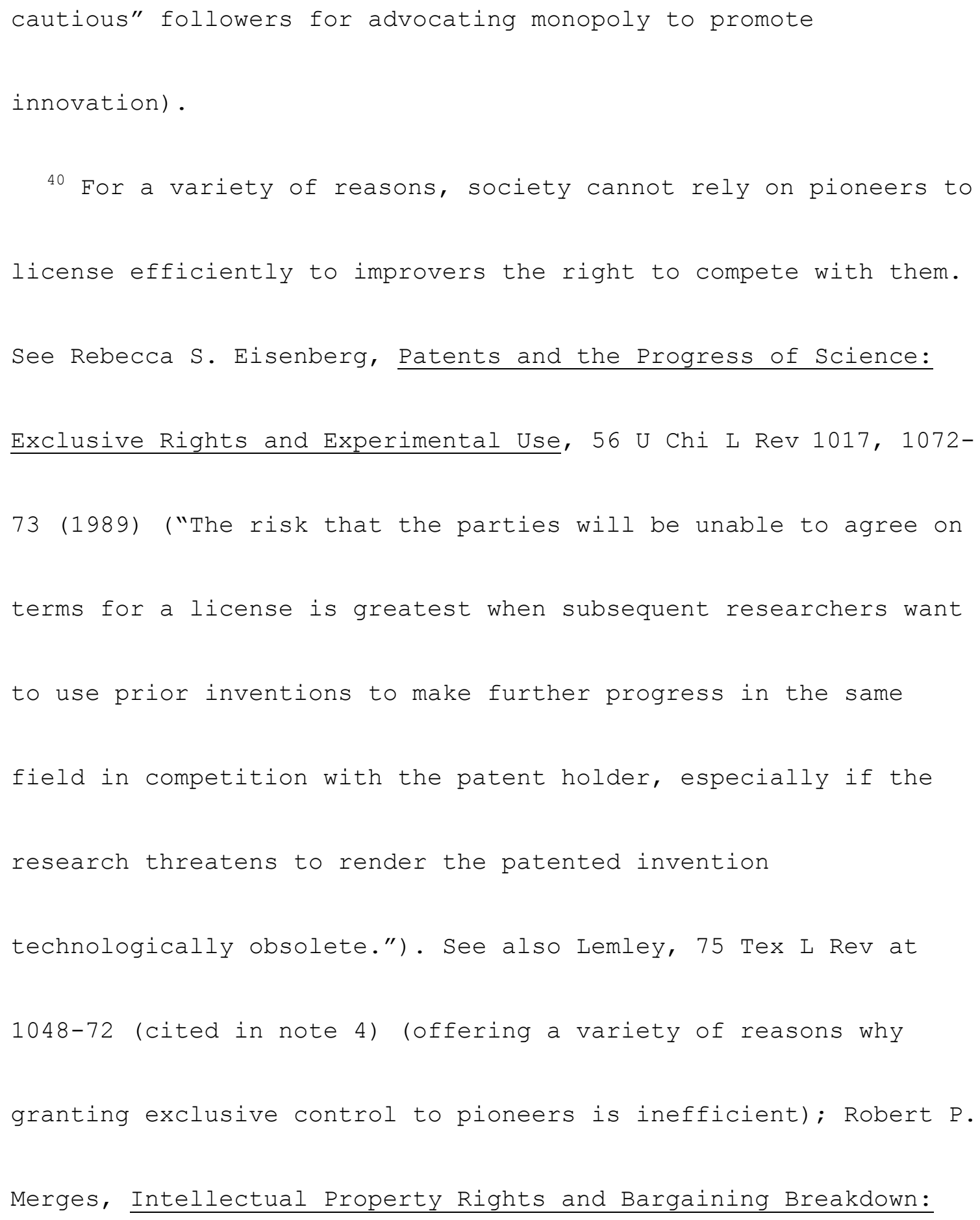


The Case of Blocking Patents, 62 Tenn L Rev 75, 78-91 (1994)

(focusing on bargaining failures between pioneers and radical

improvers); Merges and Nelson, 90 Colum L Rev at 862-66 (cited in

note 4) (discussing the effect of improvement patents on

prospects for bargaining).

41 To the extent that intellectual property gives creators some

power over price, market discipline will be imperfect. See note

27. Further, the intellectual property rights that do confer

monopoly power are the very ones most likely to be the subject of

a significant search for improvements.

42 See Dan L. Burk and Mark Lemley, Policy Levers in Patent

Law, working paper 188-210 (2003) (forthcoming in 89 Va L Rev).

43 See, for example, Suzanne Scotchmer, The Role, Value, and

Limits of S\&T Data and Information in the Public Domain for

Innovation and the Economy 7 (working paper 2002, on file with 


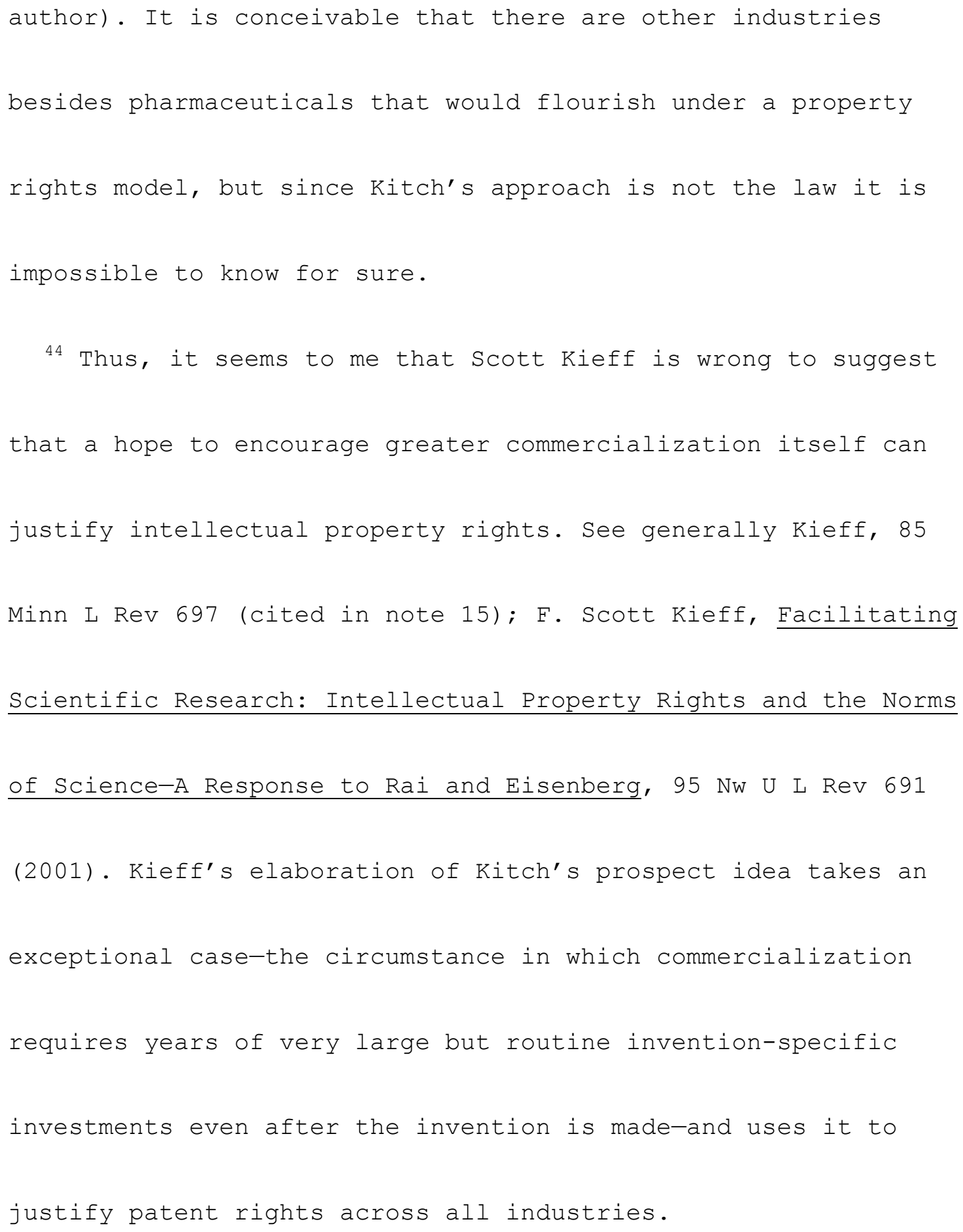


45 Garrett Hardin, The Tragedy of the Commons, 162 Science 1243

(1968)

46 Landes and Posner, $70 \mathrm{U}$ Chi L Rev at 475 (cited in note 22).

47 See Gerard N. Magliocca, One and Inseparable: Dilution and

Infringement in Trademark Law, 85 Minn L Rev 949, 975-82 (2001).

See also Robert C. Denicola, Institutional Publicity Rights: An

Analysis of the Merchandising of Famous Trade Symbols, 62 NC L

Rev 603, 637-38 (1984) (comparing market oversaturation with

trademarks to "inefficient exploitation in the traditional

example of the public common" and arguing that "if use by some

does diminish the value of the mark to others, a mechanism to

manage its exploitation may be desirable").

48 See, for example, Mark F. Grady, A Positive Economic Theory

of the Right of Publicity, 1 UCLA Ent L Rev 97, 103-04 (1994)

("The legal right of publicity can be understood as a fishing 


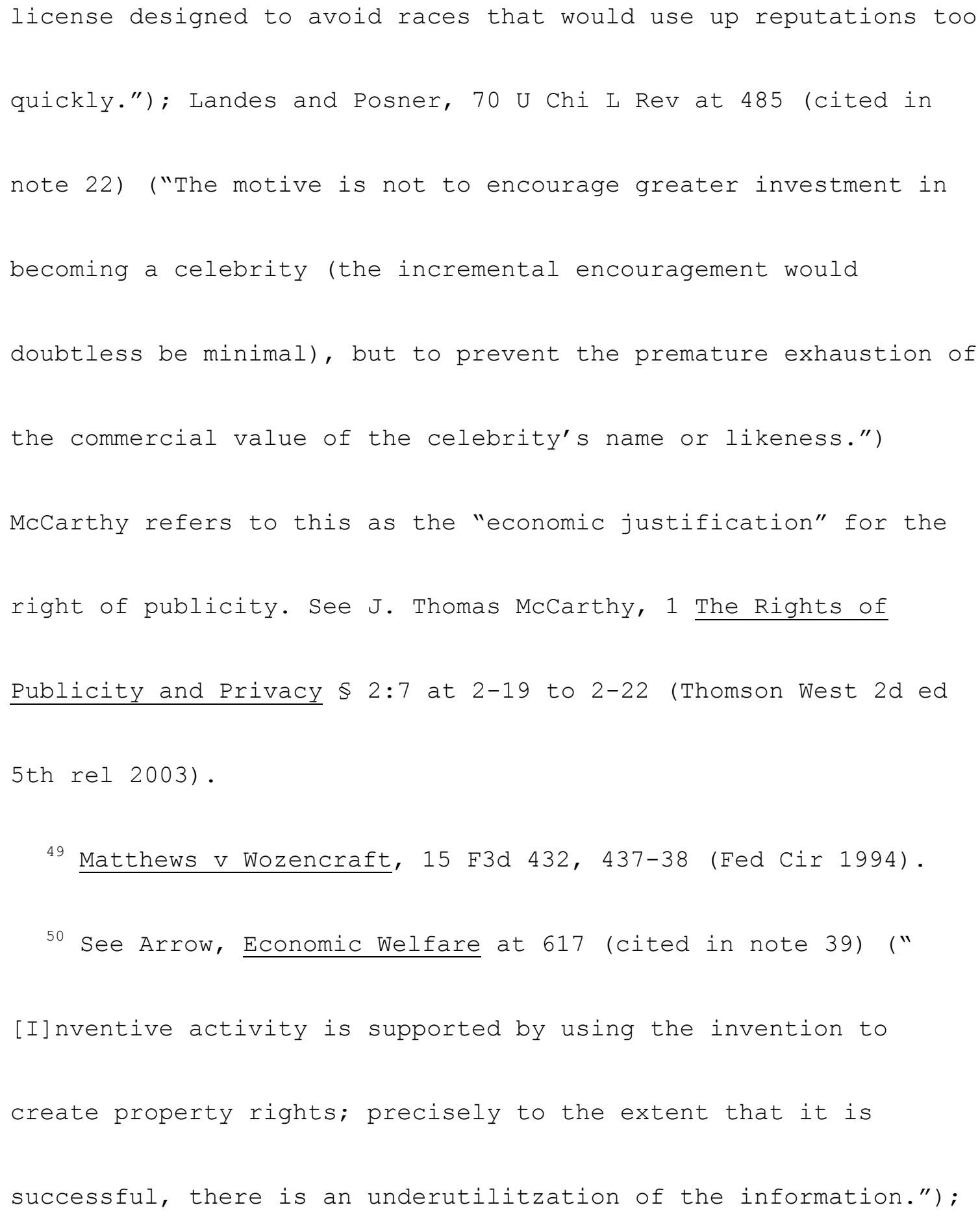




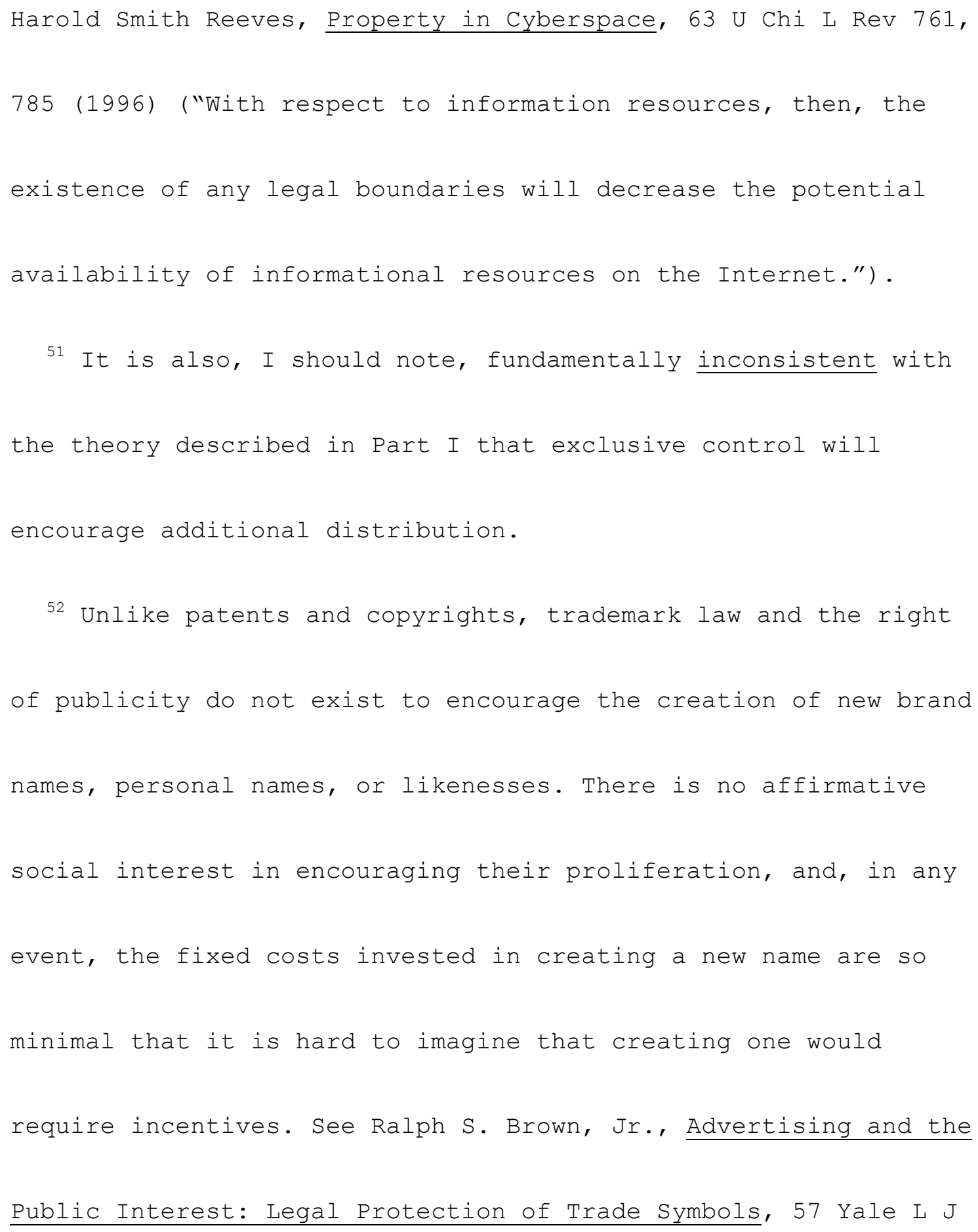




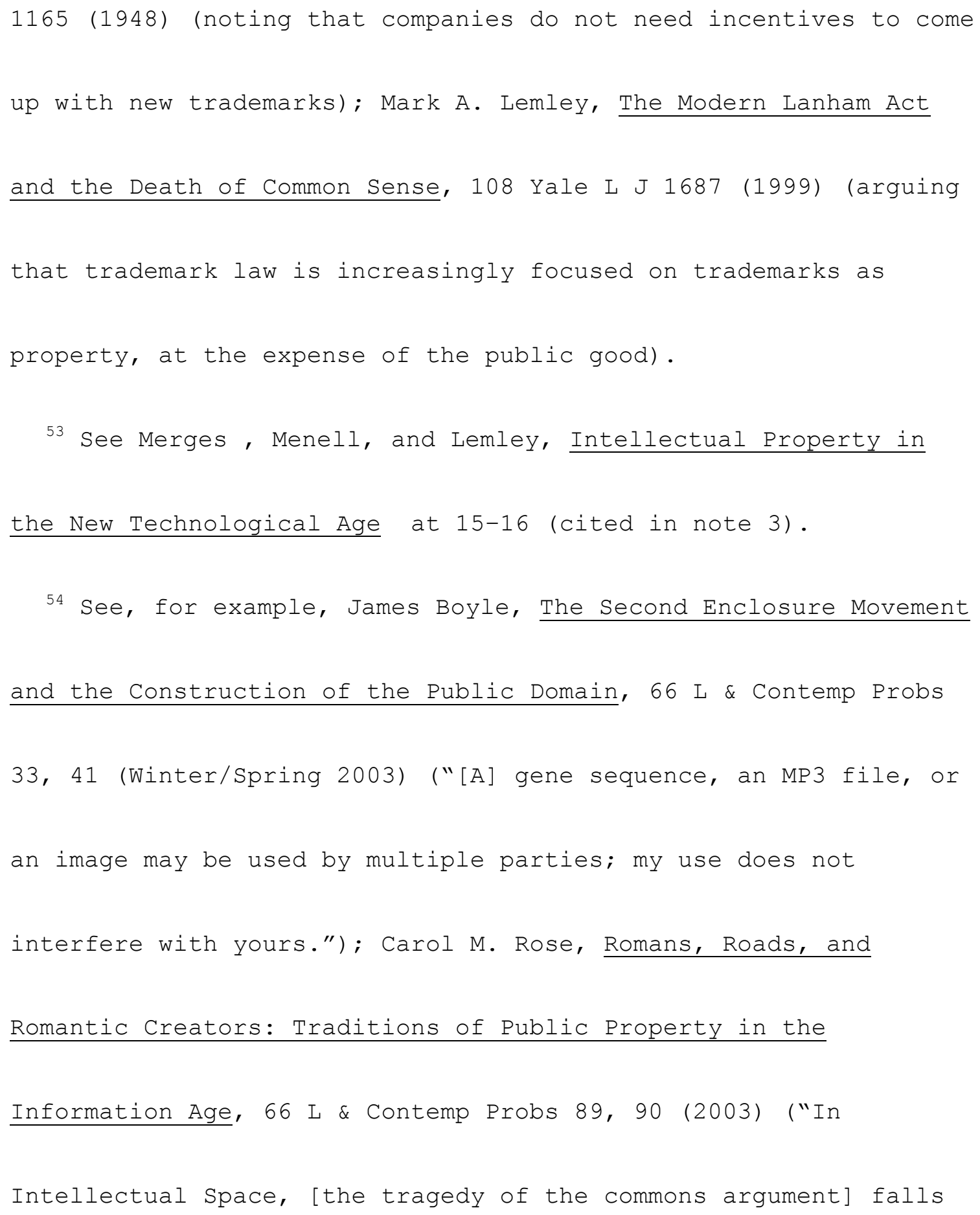




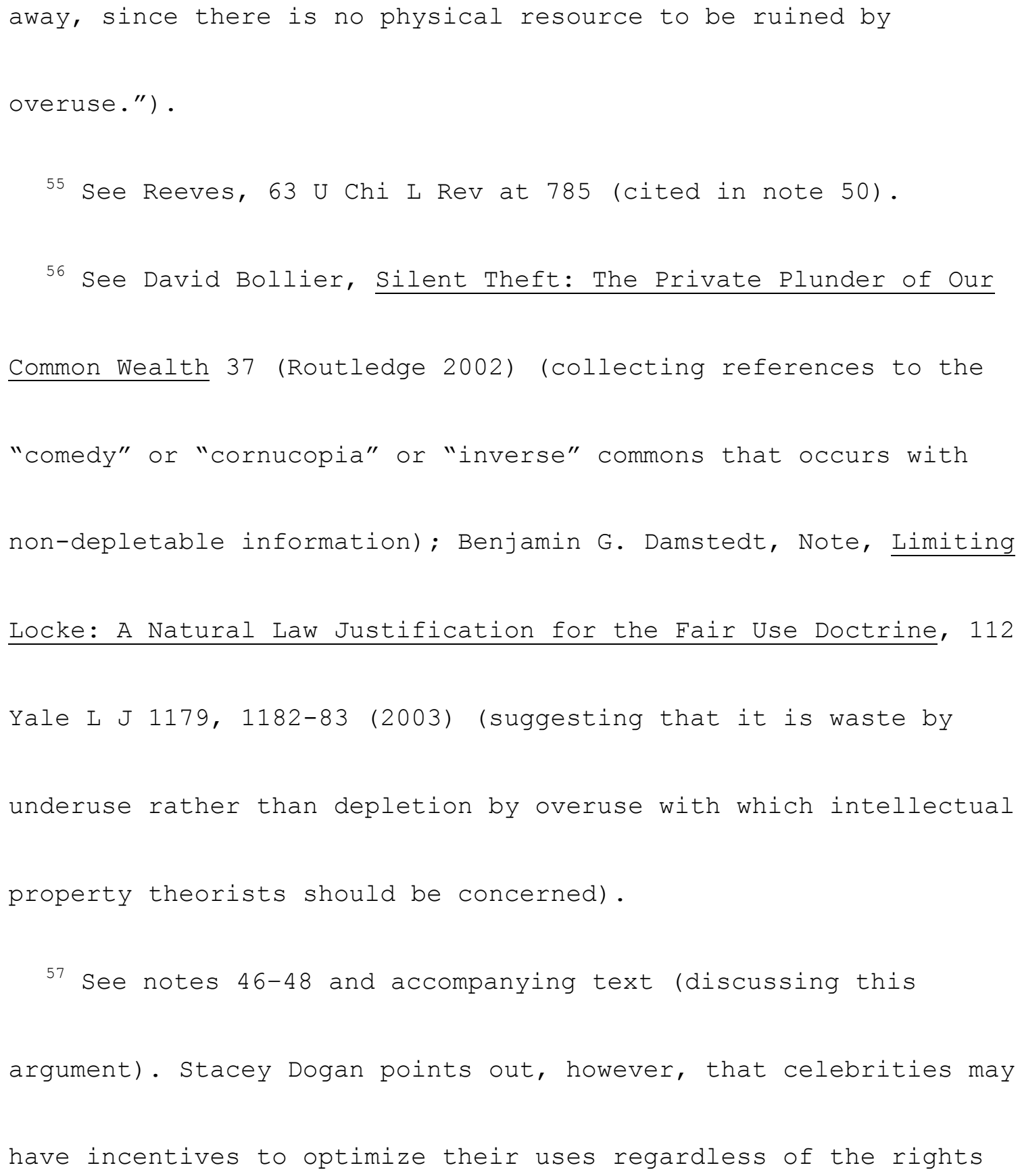




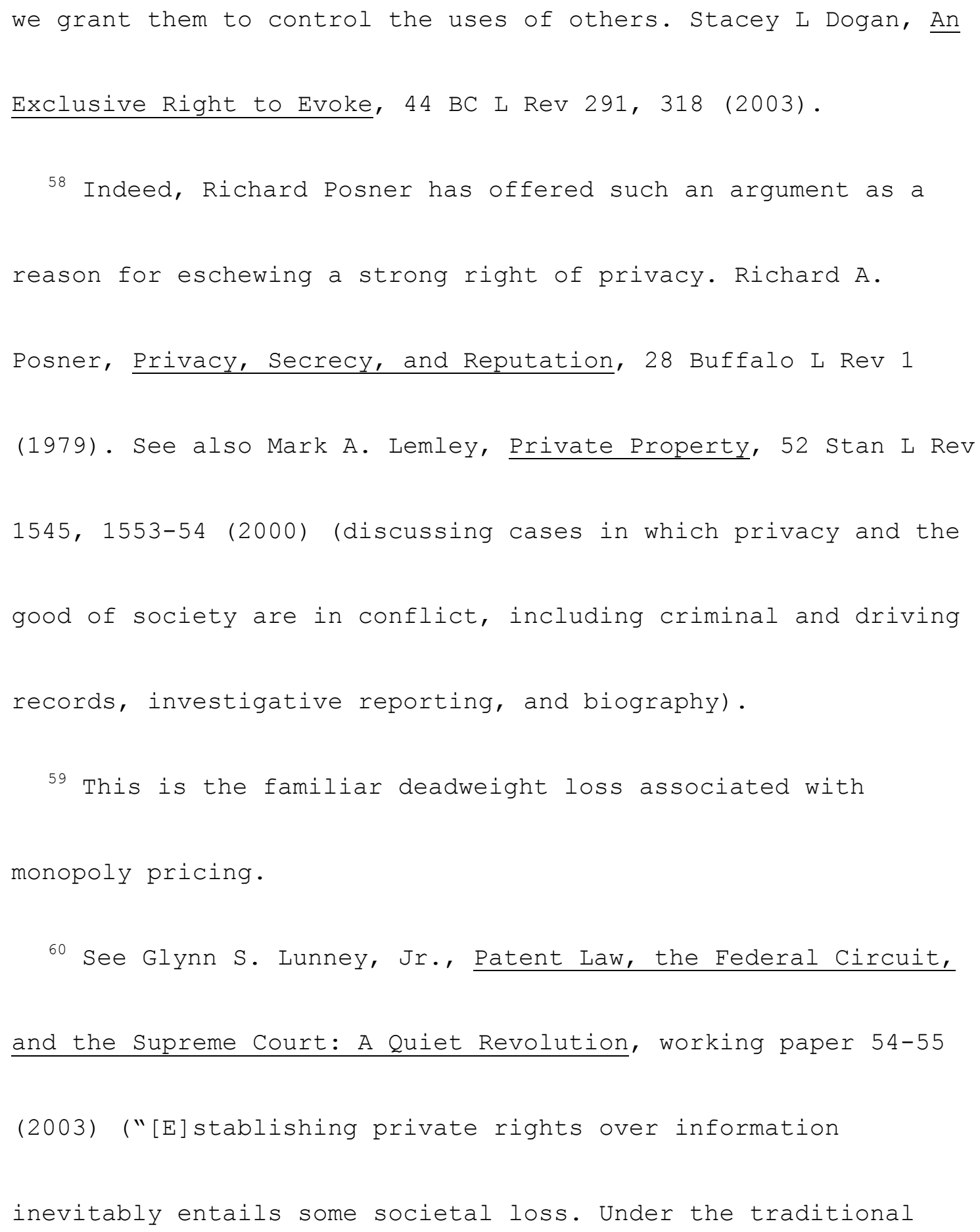




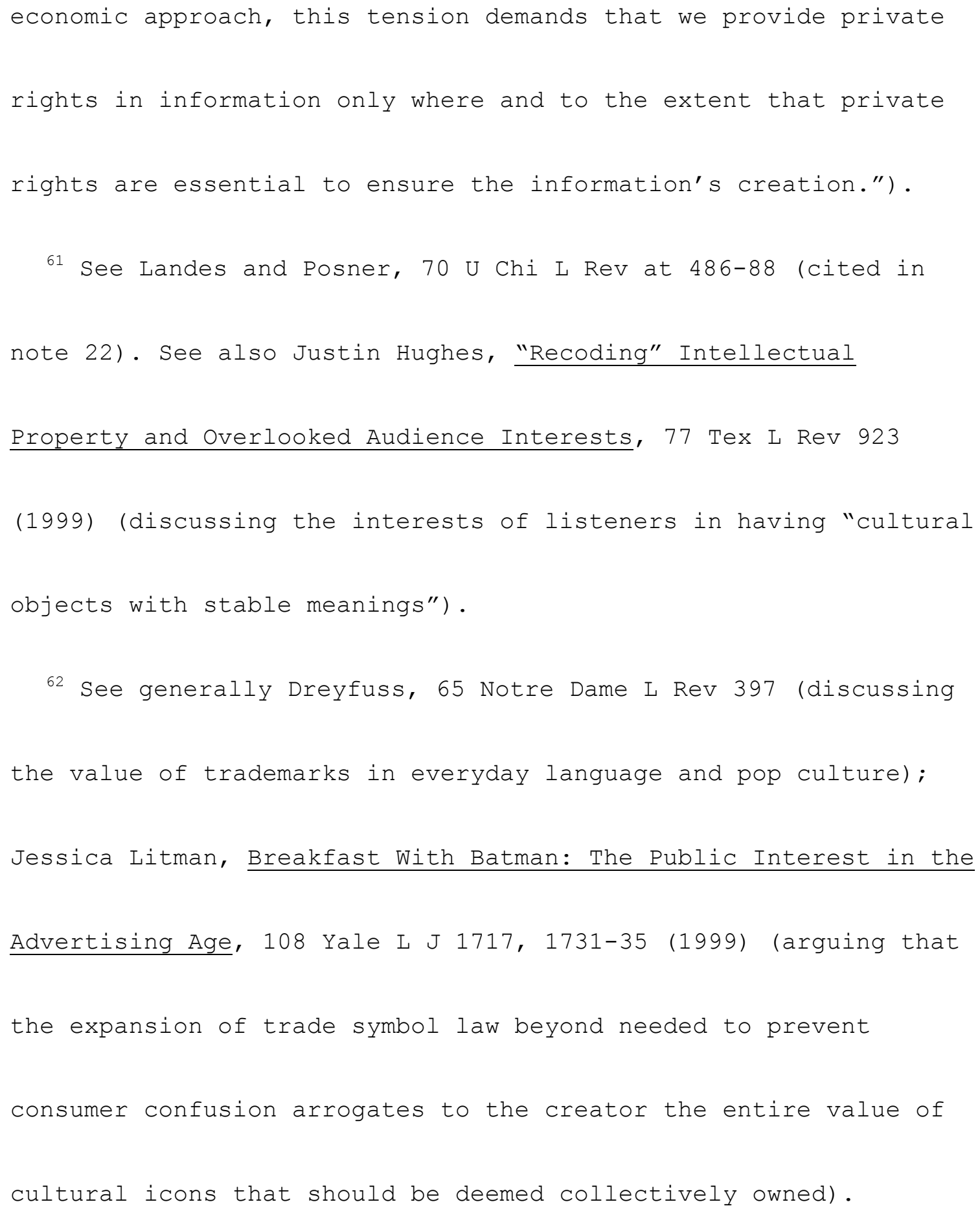


64 Alice Randall, The Wind Done Gone (Houghton Mifflin 2001)

(retelling the story of Gone With the Wind from a slave's

perspective)

65 Where a work is truly iconic, even repeated debasement is unlikely to affect public perceptions. Justin Hughes observes that the statue of Liberty, the Mona Lisa, Mount Rushmore, and the Eiffel Tower retain their iconic status despite repeated uses and abuses in many different contexts. So too do the works of Shakespeare and the characters Frankenstein (and his monster), Dracula, Scrooge, Uncle Sam, and King Arthur. Hughes, 77 Tex L Rev at 961 (cited in note 61).

66 For example, Cervantes was moved to write the second part of Don Quixote more quickly because another author published an unauthorized sequel to the first part, and the book is arguably 


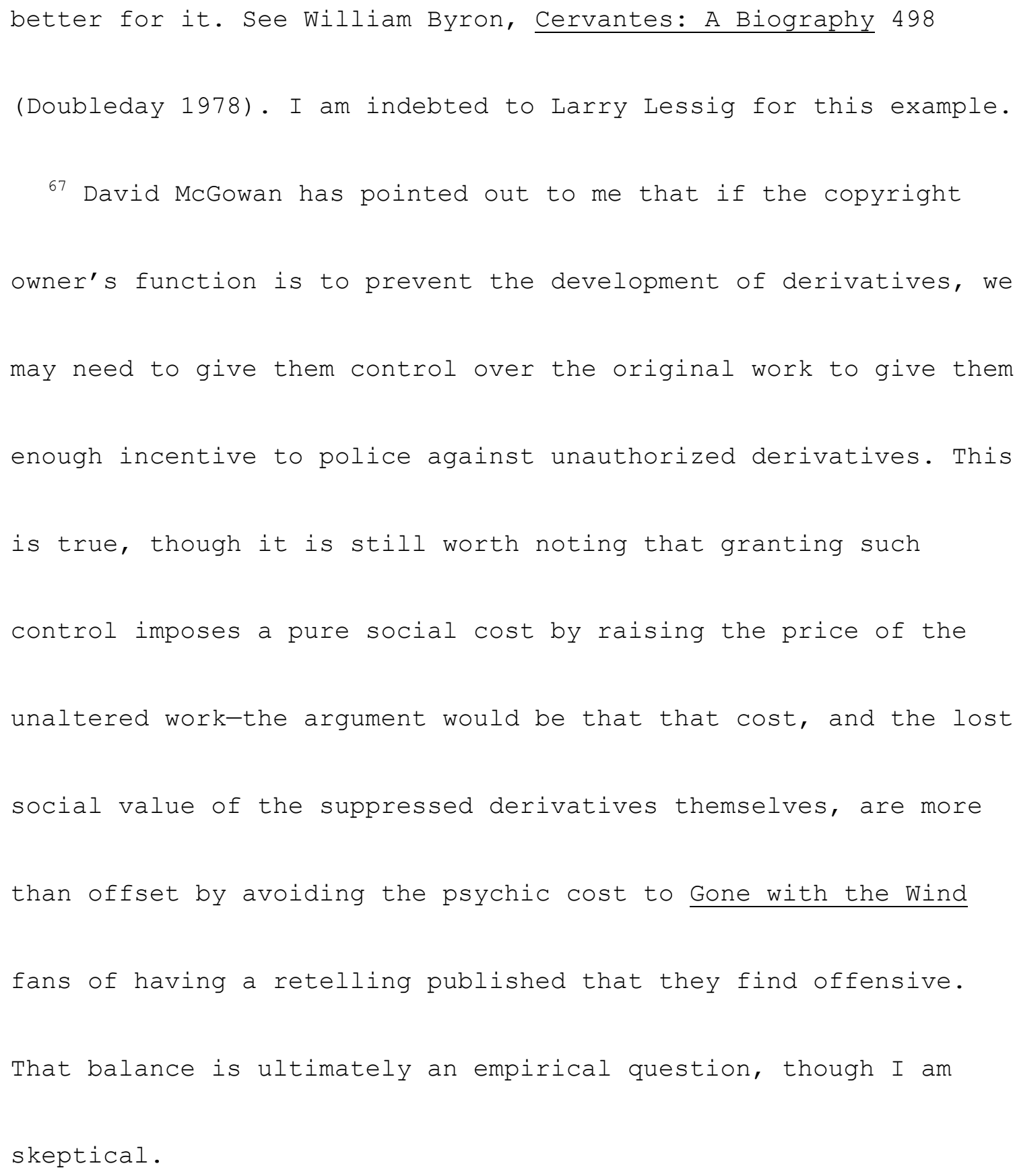




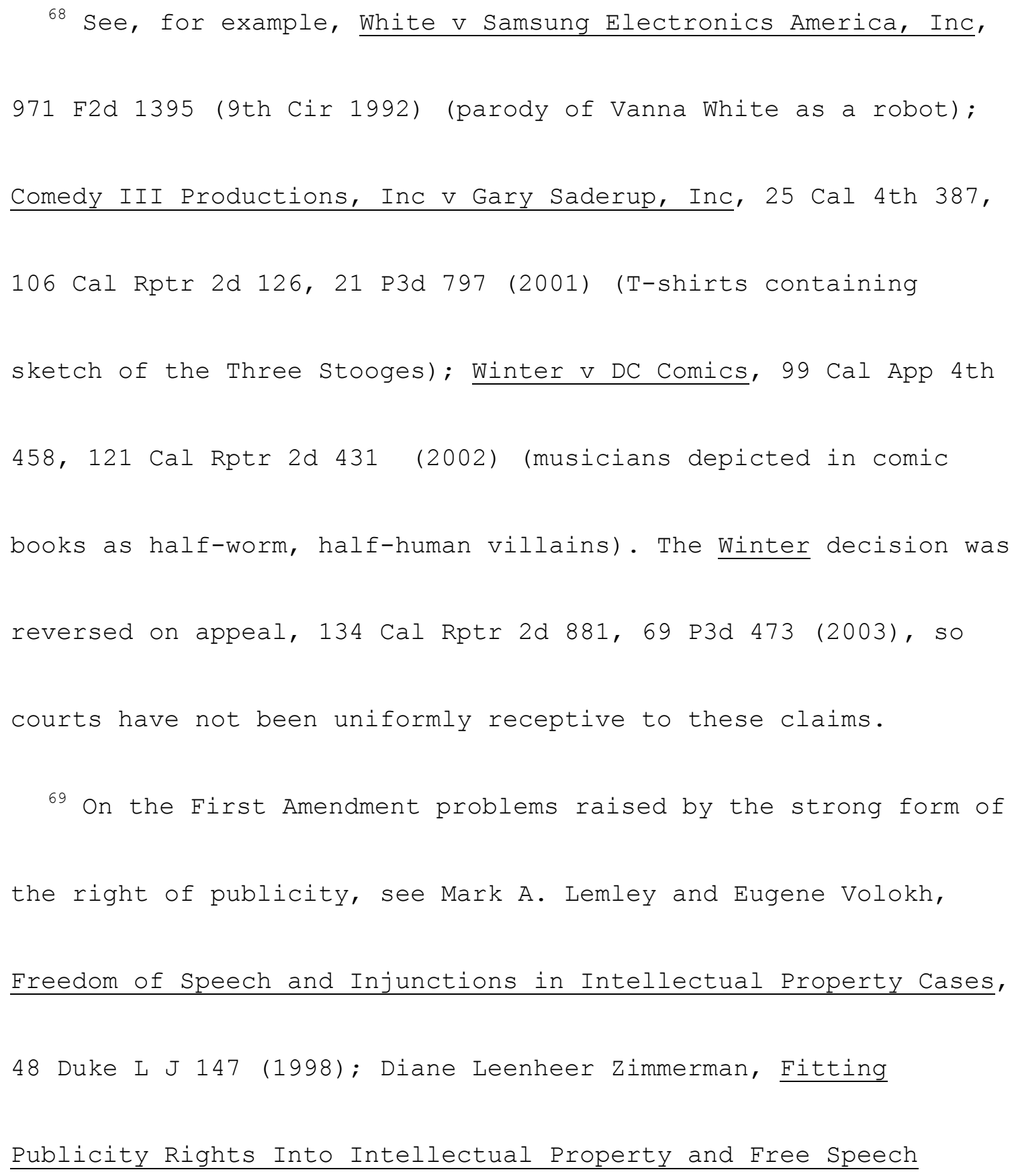




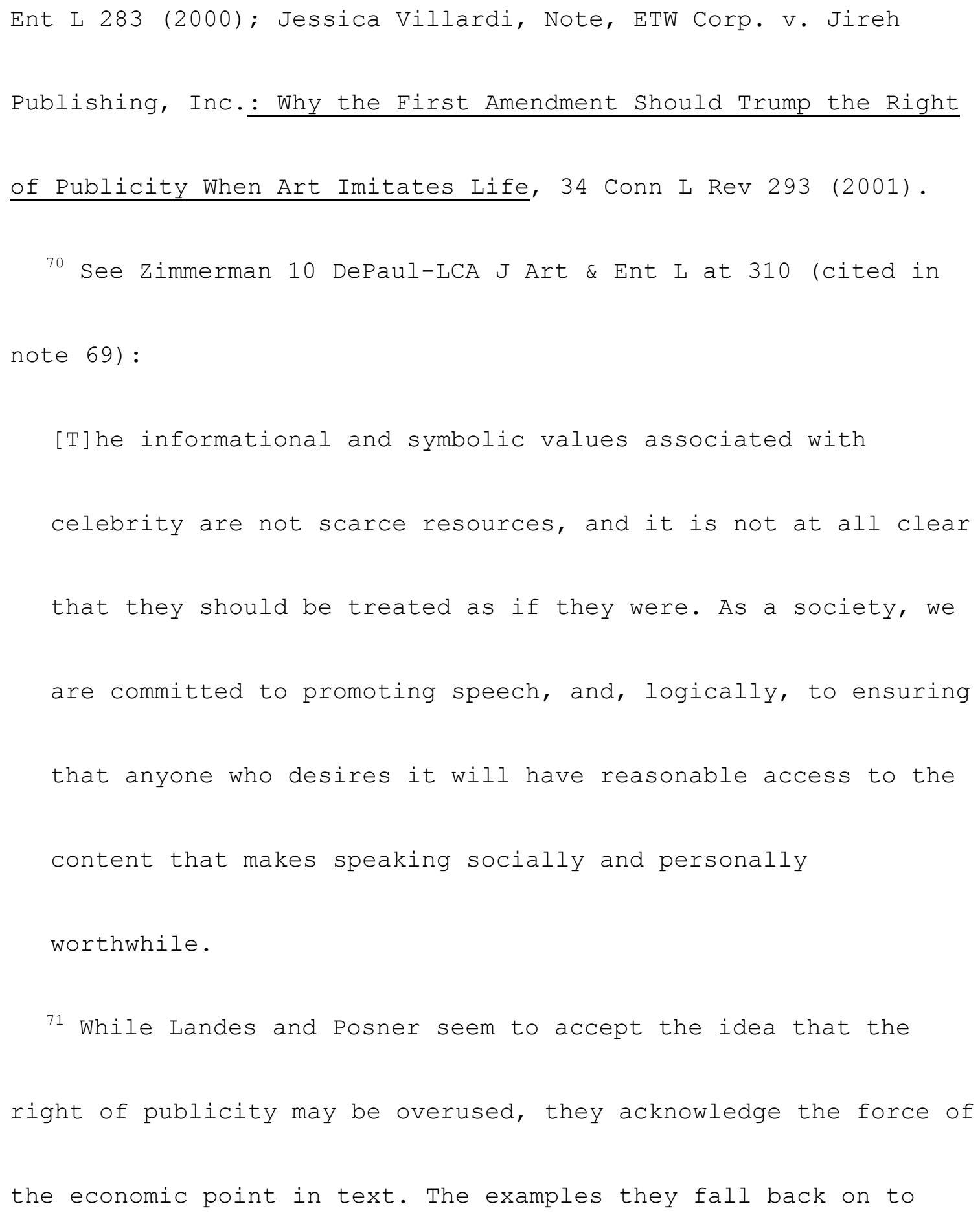




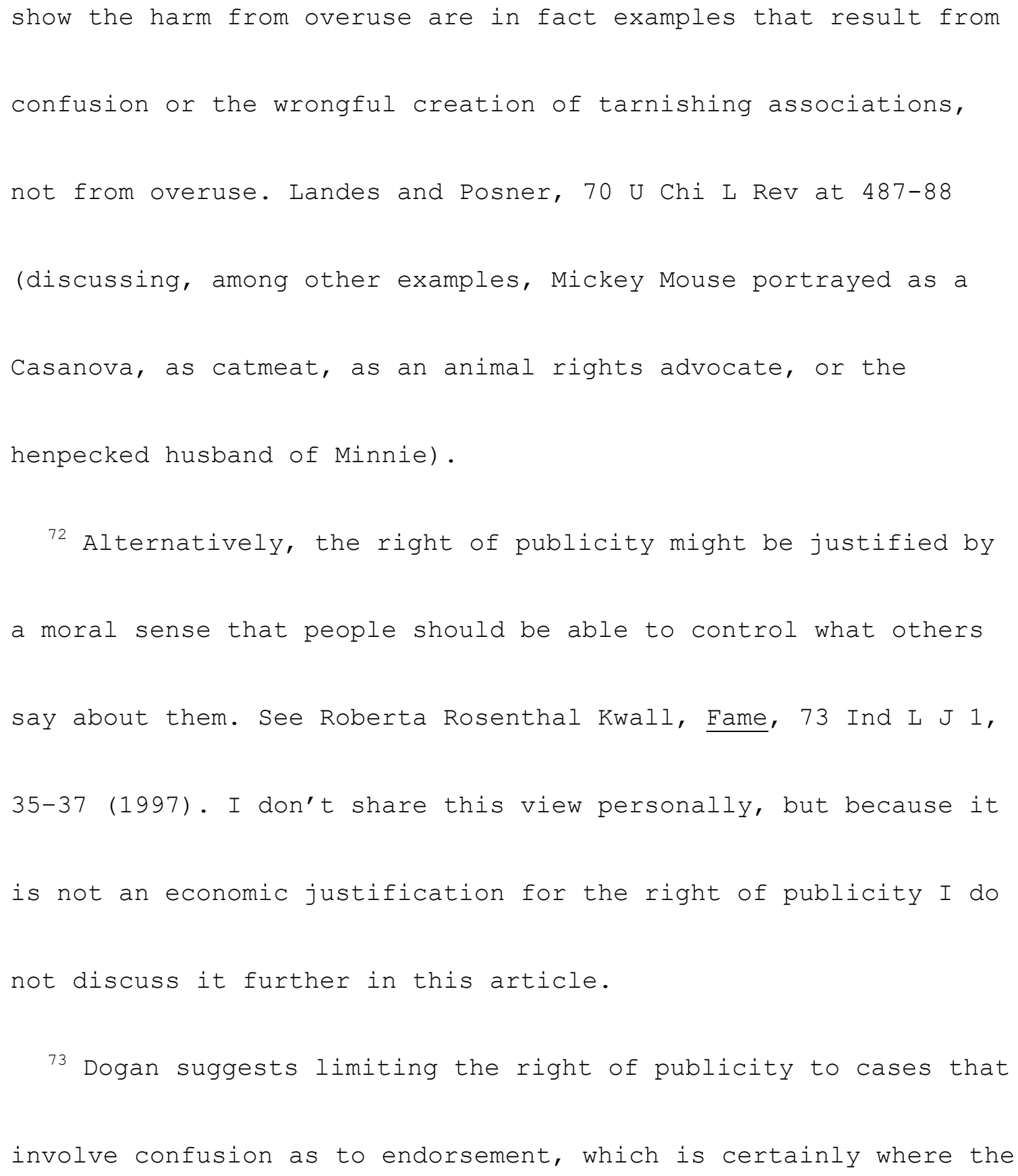




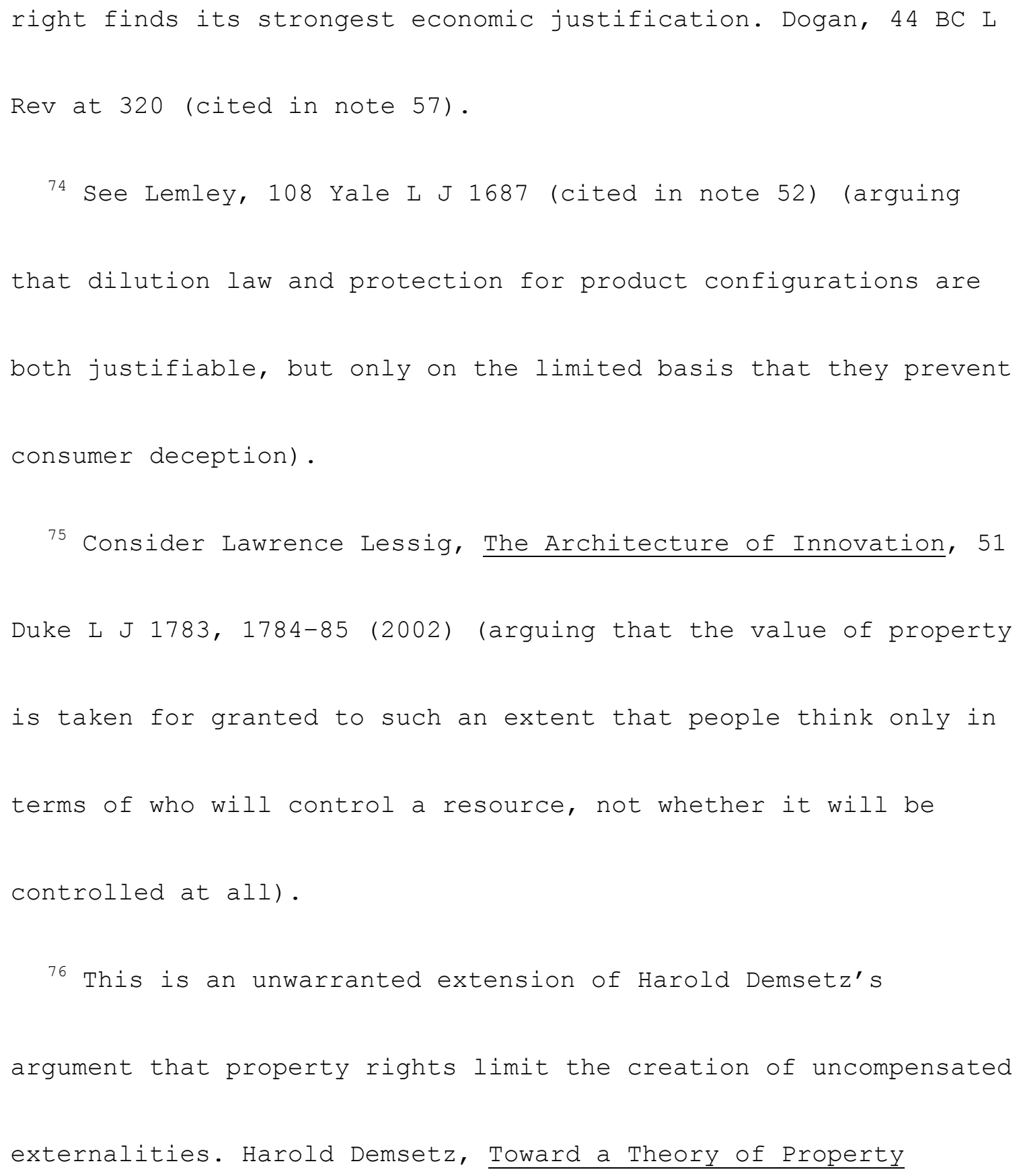




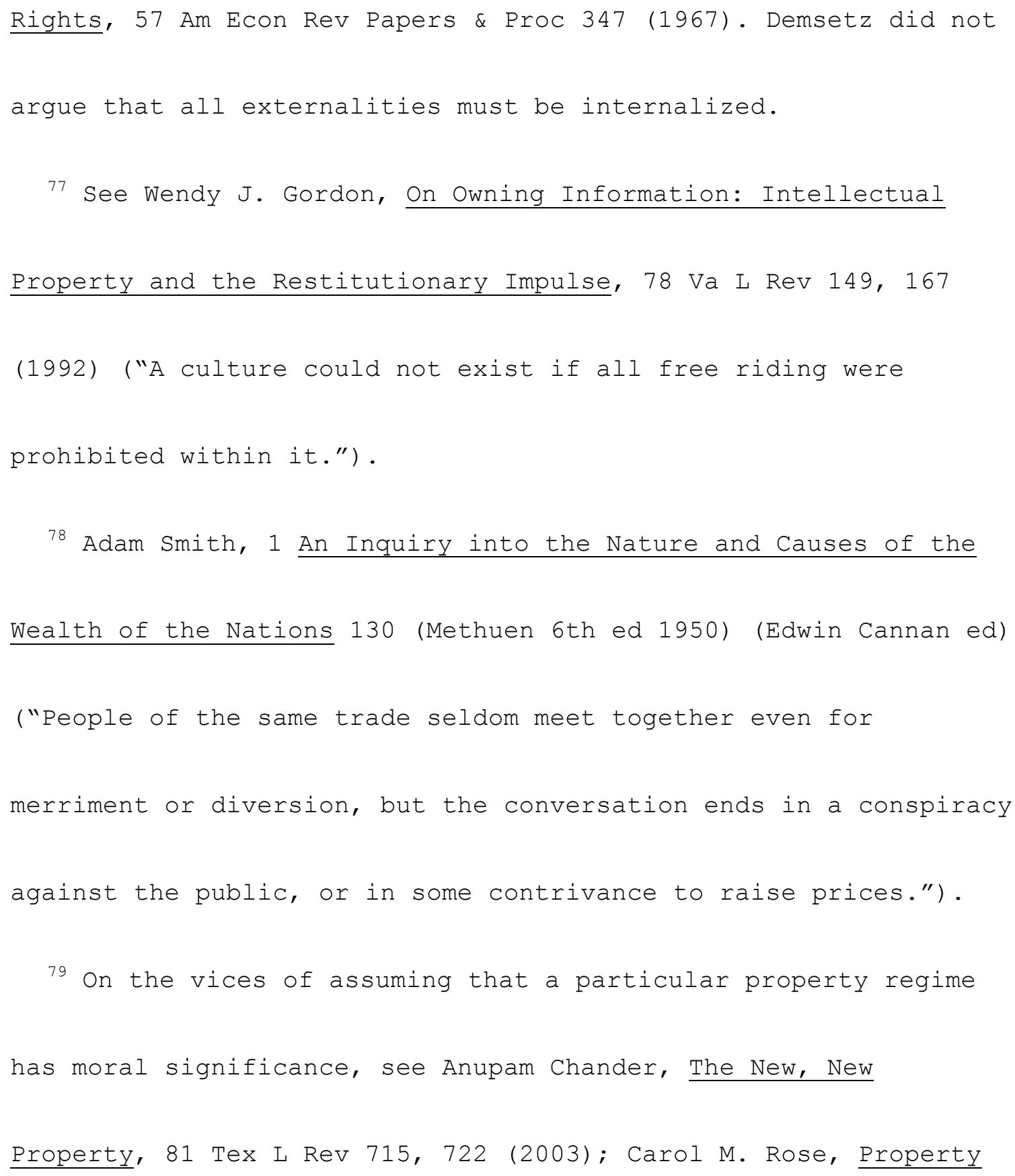




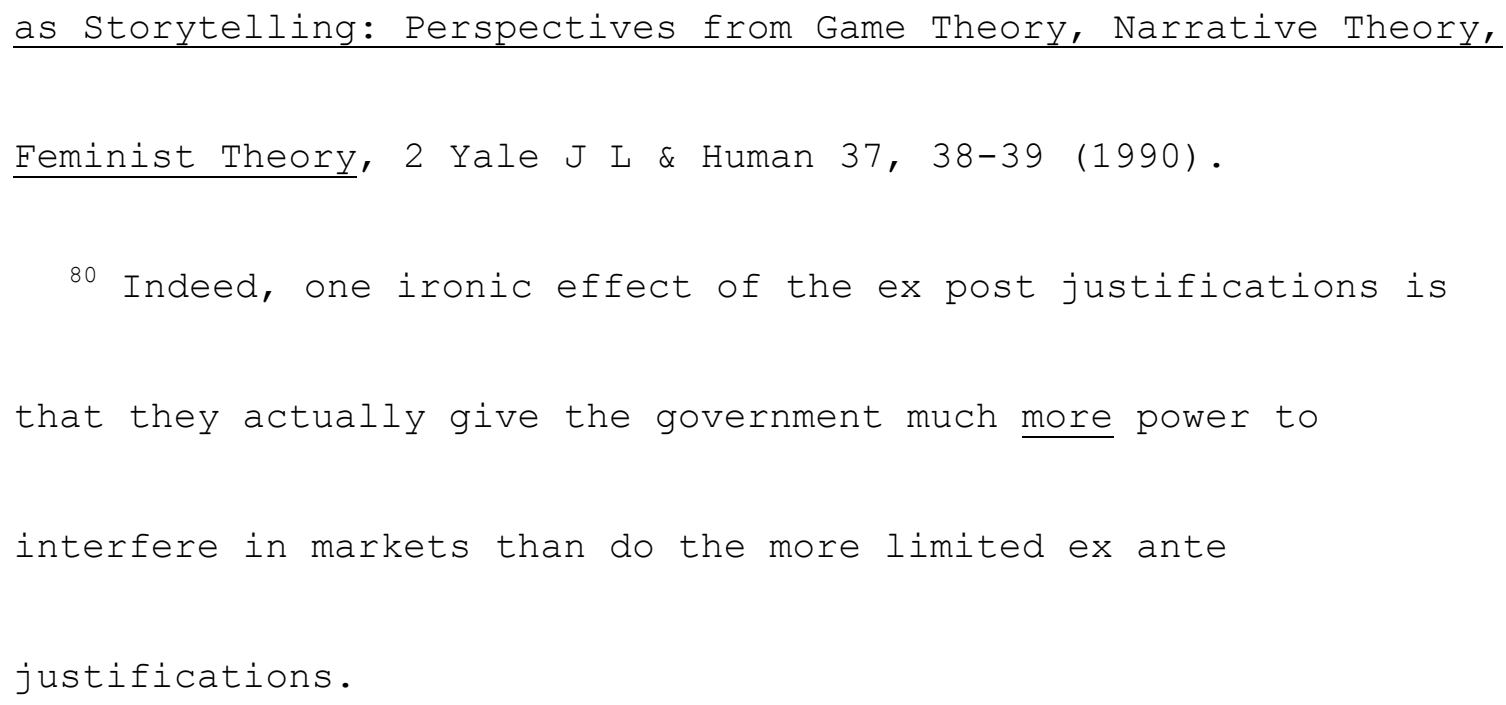

